\title{
Advanced Bioethanol Production: From Novel Raw Materials to Integrated Biorefineries
}

\author{
Aleta Duque (D), Cristina Álvarez, Pablo Doménech (D), Paloma Manzanares * $\mathbb{D}$ and Antonio D. Moreno *(D) \\ Advanced Biofuels and Bioproducts Unit, Department of Energy, Research Centre for Energy, Environment and \\ Technology (CIEMAT), 28040 Madrid, Spain; aleta.duque@ciemat.es (A.D.); cristina.alvarez@ciemat.es (C.Á.); \\ pablo.domenech@ciemat.es (P.D.) \\ * Correspondence: p.manzanares@ciemat.es (P.M.); david.moreno@ciemat.es (A.D.M.); \\ Tel.: +34-91-346-6737 (P.M.); +34-91-346-6054 (A.D.M.)
}

Citation: Duque, A.; Álvarez, C.; Doménech, P.; Manzanares, P.; Moreno, A.D. Advanced Bioethanol Production: From Novel Raw Materials to Integrated Biorefineries. Processes 2021, 9, 206. https:// doi.org/10.3390/pr9020206

Academic Editor: Adam Smoliński Received: 28 December 2020

Accepted: 19 January 2021

Published: 22 January 2021

Publisher's Note: MDPI stays neutral with regard to jurisdictional claims in published maps and institutional affiliations.

Copyright: (c) 2021 by the authors. Licensee MDPI, Basel, Switzerland. This article is an open access article distributed under the terms and conditions of the Creative Commons Attribution (CC BY) license (https:// creativecommons.org/licenses/by/ $4.0 /)$.

\begin{abstract}
The production of so-called advanced bioethanol offers several advantages compared to traditional bioethanol production processes in terms of sustainability criteria. This includes, for instance, the use of nonfood crops or residual biomass as raw material and a higher potential for reducing greenhouse gas emissions. The present review focuses on the recent progress related to the production of advanced bioethanol, (i) highlighting current results from using novel biomass sources such as the organic fraction of municipal solid waste and certain industrial residues (e.g., residues from the paper, food, and beverage industries); (ii) describing new developments in pretreatment technologies for the fractionation and conversion of lignocellulosic biomass, such as the bioextrusion process or the use of novel ionic liquids; (iii) listing the use of new enzyme catalysts and microbial strains during saccharification and fermentation processes. Furthermore, the most promising biorefinery approaches that will contribute to the cost-competitiveness of advanced bioethanol production processes are also discussed, focusing on innovative technologies and applications that can contribute to achieve a more sustainable and effective utilization of all biomass fractions. Special attention is given to integrated strategies such as lignocellulose-based biorefineries for the simultaneous production of bioethanol and other high added value bioproducts.
\end{abstract}

Keywords: biofuels; biochemical route; biomass fractionation; bio-based products

\section{Introduction}

The consumption of fossil-derived fuels in the transport sector poses an important environmental challenge since it is currently responsible for $24 \%$ of direct $\mathrm{CO}_{2}$ emissions at the global level (8.2 Gt in 2019). Road vehicles-cars, trucks, and buses-account for nearly $75 \%$ of total $\mathrm{CO}_{2}$ emissions in transport [1]. The magnitude of this impact, which has been getting worse in recent decades, makes the use of renewable and sustainable sources for the production of alternative biofuels imperative, among which biomass plays a key role. The intense work involving research, governmental and industry sectors has turned biomass-based liquid fuels (mostly bioethanol and biodiesel) into an actual alternative to the use of conventional fuels (gasoline and diesel) today. These liquid biofuels are considered essential elements to improve energy security in terms of supply, mitigate climate change, and support rural development at the global level $[2,3]$.

In the transport sector, bioethanol is the most important biofuel worldwide, with $70.5 \%$ of the total shares and 142.6 billion liters produced in 2019 [4]. The United States and Brazil are the major bioethanol producers, accounting for $84 \%$ of the total production worldwide. The European Union is third in place reaching 5443 million liters (5\% of global production) in 2019. Currently, fuel ethanol is mainly produced from food-related crops such as sugarcane, corn, wheat, and barley. This production has been known as first-generation (1G) bioethanol and the technology is mature at the industrial level. In $2019,94 \%$ of the total bioethanol production in the United States was based on corn starch. 
Brazil, on the other hand, mainly obtains bioethanol (99\% of the total production) from sugarcane. In the EU, bioethanol is produced from different feedstock including wheat $(18.7 \%)$, maize $(19.6 \%)$, sugar beet $(57.9 \%)$, barley $(1.9 \%)$, and rye $(1.9 \%)$ [5].

$1 \mathrm{G}$ bioethanol production created a strong controversy around the negative impact that the extensive use of cereal grain in Europe and the USA may have on food security at a global scale. As a result, several directives have been put into action in different world regions to establish sustainability criteria aiming at protecting the use of land for food and feed and assuring that biofuels involve measurable greenhouse gas savings in comparison to fossil fuels. Moreover, in the particular case of EU, the new Directive on Renewable Energy (RED II) establishes that conventional food-based biofuels, including bioethanol, will be limited at a maximum of $7 \%$ of final consumption of energy in the road and rail transport sector in 2030 [6]. This scenario has paved the way for the introduction of the so-called advanced biofuels that are produced from nonfood biomass materials such as lignocellulosic feedstocks.

Lignocellulosic bioethanol can be produced from the cellulosic fraction of a great variety of lignocellulosic feedstocks through the biochemical conversion pathway, which is based in hydrolysis and fermentation processes. This cellulosic ethanol is also known as second generation $(2 \mathrm{G})$ bioethanol or advanced ethanol, in the context of this review. Cellulosic ethanol represents a promising complement to the $1 \mathrm{G}$ ethanol production and it will be undoubtedly needed to meet the foreseen demand of this biofuel in the future. In spite of the continuing research effort and large investments being made in the US and Europe to speed up the development of this route, it is still necessary to improve the cost-competitiveness of cellulosic ethanol through the introduction of innovative processes and advanced methodological approaches that result in enhanced production yields and reduced costs.

\section{Novel Raw Materials for Advanced Bioethanol Production}

Lignocellulosic biomass is one of the most promising substrates for sustainable biofuel production. In economic terms, lignocellulose is readily available and can be locally produced at low cost. Lignocellulosic materials include agricultural and forest biomass residues (e.g., cereal straws, corn stover and sugarcane bagasse, softwood, hardwood, sawdust, pruning and bark residues), dedicated energy crops, and the organic fraction of municipal and industrial wastes. These materials are abundant on earth and in many cases have no economic value. Besides this, this type of biomass cannot be used as a food resource so there is no conflict with the food industry. For this reason, lignocellulosic bioethanol is one of the most promising and eco-friendly alternatives to the first-generation bioethanol produced from food crop biomass.

Lignocellulosic biomass is mainly composed of cellulose, hemicellulose, and lignin. Cellulose is a linear polymer consisting of $\beta$-D-glucose units linked by $\beta$-1-4-glycosidic bonds. Within lignocellulosic biomass, cellulose is organized into microfibrils due to hydrogen bonds and Van der Waal's forces, through cross-linking between numerous hydroxyl groups. This makes a rigid structure and constitutes the principal component of the plant cell walls. Hemicellulose is a heteropolysaccharide composed of pentoses (xylose and arabinose) and/or hexoses (glucose, galactose, and mannose), sugars with 50-200 units. Although the composition varies depending on the biomass, hemicelluloses are highly branched with acetyl groups and small amounts of glucuronic acid. The third major component in lignocellulose is lignin, which provides structural strength to the plant. Lignin is a heterogeneous, amorphous, and highly branched aromatic polymer made of coniferyl, sinapyl, and $p$-coumaryl alcohol units. Table 1 shows the chemical composition of diverse lignocellulosic biomass used for bioethanol production. 
Table 1. Chemical composition of diverse biomass waste.

\begin{tabular}{|c|c|c|c|c|c|}
\hline Biomass Waste & Type of Biomass & Cellulose \% & Hemicellulose \% & Lignin \% & Reference \\
\hline \multirow{2}{*}{ Agriculture residues } & Corn stover & $38-40$ & 28 & $7-21$ & [7] \\
\hline & Barley straw & 33 & 26 & 19 & [8] \\
\hline \multirow{3}{*}{ Forestry residues } & Poplar sawdust & 44 & 19 & 25 & [9] \\
\hline & Eucalyptus & 54 & 18 & 21 & [10] \\
\hline & $\begin{array}{l}\text { Municipal forestry and } \\
\text { greening waste }\end{array}$ & 33 & 26 & 19 & [11] \\
\hline \multirow{3}{*}{ Energy crops } & Miscanthus $x$ giganteus & $41-53$ & $20-25$ & $20-23$ & [12] \\
\hline & $\begin{array}{c}\text { Napier grass } \\
\text { (Pennisetum purpureum) }\end{array}$ & $40-50$ & $20-40$ & $10-25$ & [13] \\
\hline & $\begin{array}{c}\text { Deenanath grass } \\
\text { (Pennisetum pedicellatum) }\end{array}$ & 32 & 23 & 3 & [14] \\
\hline
\end{tabular}

The sugars contained in these feedstocks can be transformed into bioethanol by means of biotechnological processes through several steps and different configuration strategies. The maximum theoretical yield of the biochemical bioethanol production processes is $0.51 \mathrm{~g}$ of bioethanol/g of monosaccharide (independently of using C5 or C6 sugars). However, the efficiency of bioethanol production is influenced by different factors. Biomass recalcitrance is one of the most important factors to consider during advanced bioethanol production as it highly affects the accessibility of carbohydrates and thus prevents the release of fermentable sugars. To overcome biomass recalcitrance, different pretreatment technologies have been developed to guarantee the accessibility to carbohydrates. These methods are discussed in detail in Section 3.

The use of different biomass feedstocks in the context of advanced bioethanol production is discussed in the following subheadings.

\subsection{Energy Crops}

Crops, whose partial or total production is used as raw material to generate usable energy, are considered energy crops. In general, these crops produce great amounts of biomass per unit of area and time. The main characteristics for the selection of energy crops include rapid growth (short period from planting to harvest) and the capacity to grow under severe weather and poor soil conditions (where other crops will have low and unstable yields) [15].

Energy crops are generally divided into two types: herbaceous and woody energy crops. Herbaceous energy crops mostly belong to perennial grasses, including switchgrass (Panicum virgatum), miscanthus (Miscanthus spp.), and giant reed (Arundo donax) as well as others. On the other hand, with a relatively fast growth, short rotation woody crops included poplar and eucalyptus. Both herbaceous and woody energy crops may contribute to reduce soil erosion and to increase soil carbon and soil fertility in poor soils. Furthermore, herbaceous energy crops can be grown on degraded land (i.e., areas with low fertility and poor-quality mineral composition) $[16,17]$, without affecting the intrinsic characteristics of bioethanol.

Switchgrass and Miscanthus spp. are probably the most studied lignocellulosic energy crops. Smullen et al. [18] investigated the conversion of switchgrass after subjecting it to different pretreatment methods $\left(\mathrm{NaOH}, \mathrm{NH}_{3}(\mathrm{aq}), \mathrm{H}_{2} \mathrm{SO}_{4}\right.$ and $\left.\mathrm{CH}_{3} \mathrm{OH}\right)$, with methanol being the most effective pretreatment method and allowing a final yield of $0.32 \mathrm{~g}$ of ethanol/g of glucose with $97 \%$ conversion yields.

\subsection{Forest Biomass}

Forest biomass, mainly woody materials such as branches, leaves, and lops, has been used as feedstock for bioethanol production. Wood can be classified into softwood (from gymnosperms) or hardwood (from angiosperms). Major differences between softwoods 
and hardwoods include growth rates and densities. Hardwoods usually exhibit slower growth and are therefore more dense than softwoods [19].

This group plays an important environmental role for the reduction in $\mathrm{CO}_{2}$ levels in the atmosphere and the preservation of marginal land. One of the major advantages of using forest biomass as feedstock when compared to other raw materials is its flexibility in harvesting time, since these materials do not depend on seasonality.

As an example of forestry resources, Eucalyptus nitens bark is a residue commonly obtained during the manufacturing of eucalyptus trees in the pulping industry. During this process, 20 tons of bark can be produced per 100 tons of pulp product [20]. This residue was used by Romaní et al. [21] as an alternative source for producing $252 \mathrm{~L}$ of bioethanol per ton of biomass, using organosolv as pretreatment technology and simultaneous saccharification and fermentation (SSF) as a process strategy.

More interesting forest-derived residues are boards (including fiberboard, chipboard, and block board) typically made from reeds, wood chips, and branches. These panels are normally incinerated after their use. However, these materials can be used instead for bioethanol production as they mainly contain lignocellulose (more than $85 \%$ of its composition). The use of these materials for bioethanol production was investigated by Zhao et al. [22], who achieved bioethanol conversion yields as high as $84-95 \%$ of the theoretical, using phosphoric acid and hydrogen peroxide as pretreatment processes followed by $72 \mathrm{~h}$ of SSF.

\subsection{Agricultural Residues}

According to the Food and Agriculture Organization (FAO) of the United Nations $(\mathrm{UN})$, agricultural residues are defined as "a crop lost during the year at all stages between the farm and the household level during handling, storage, and transport" [http:/ / www. fao.org/]. This includes materials such as stubble, straw, husks, seeds, and bagasse, thus covering both field and processing residues. Only in the United States, the amount of agricultural residues available for bioenergy production is estimated to be 240 million dry t/year by 2030 [23].

A great proportion of agricultural residues is derived from rice, wheat, corn, and sugarcane, with rice straw being the most abundant agricultural residue worldwide. Sarkar et al. [24] estimated the bioethanol potential of these feedstocks, reporting the possibility of obtaining 205 billion L/year from rice straw [7], 104 billion L/year from wheat straw, 58.6 billion L/year from corn straw, and 51.3 billion L/year from sugarcane bagasse.

Agricultural wastes are less recalcitrant than forestry and energy crops due to the lower lignin content. When comparing the digestibility of non-pre-treated bioenergy crops and agricultural residues, sugarcane bagasse, corn stover, wheat straw, and rice straw resulted in $47 \%, 23 \%, 11 \%$ and $10 \%$ cellulose hydrolysis yields, respectively, while common reed, switchgrass, miscanthus, poplar, and bamboo resulted in $19 \%, 17 \%, 8 \%, 7 \%$ and $3 \%$, respectively [12].

\subsection{Industrial Wastes}

Industrial wastes include all the by-product streams from existing industrial bio-based sectors such as the food industry, the pulp and paper industry, textiles, as well as 1Gbiodiesel- and bioethanol-related processes. The use of this type of biomass positively contributes to reduce the environmental impact of these industrial processes by decreasing net $\mathrm{CO}_{2}$ emissions, reducing our dependence on petroleum-based resources and increasing the economic efficiency of the processes by giving value to what is usually discarded as waste.

Within the food-derived wastes, the brewers' spent grains represent around $85 \%$ of the total amount of by-products generated by the brewing industry. Depending on the technology employed in each brewery and type of crop, this residue may contain a significant amount of fermentable sugars, ranging from $10 \%$ to $25 \%$ and $15 \%$ to $30 \%$ for 
cellulose and hemicellulose, respectively. These sugars therefore represent an attractive feedstock for bioethanol production. In this context, Rojas-Chamorro et al. [25] investigated the recovery of the fermentable sugars contained in the brewer's spent grains collected from a commercial brewery in Spain by subjecting this residue to dilute sulfuric acid under mild conditions $\left(130{ }^{\circ} \mathrm{C}\right.$ and $\left.26 \mathrm{~min}\right)$. This process allowed recovery up to $94 \%$ of the initial fermentable sugars contained in such feedstock.

Wastes derived from the pulp and paper industry are another valuable source for the production of bioethanol and other high value-added products. In 2015, 400 million tons of paper and paperboard and 188 million tons of virgin pulp were produced [26]. Spent sulfite liquor (SSL) and pulp and paper mill sludge (PPMS) are major wastes derived from papermakers with potential for bioethanol production. It is important to highlight that hardwood-derived SSL contains higher proportion of pentoses than softwood-derived SSL. Hence, pentose-fermenting microorganisms such as Scheffersomyces stipitis (formerly Pichia stipitis) must be considered for the conversion of hardwood SSL into bioethanol [27]. On the other hand, PPMS is a solid waste material with a high glucan content that can be converted into different value-added products. The chemical composition of PPMS (organic content, ash, $\mathrm{pH}$, etc.) directly depends on the type of biomass. Other factors that influence the composition of PPMS are the papermaking process and the wastewater cleaning technique [28]. Schroeder et al. [29] evaluated the production of bioethanol from PPMS under two process configuration strategies: separate hydrolysis and fermentation (SHF) and SSF. The highest ethanol yield was obtained with the SSF strategy (55.7\%), which was also reached within a shorter overall process time ( $72 \mathrm{~h}$ for the SSF vs. $84 \mathrm{~h}$ for the SHF process).

Fiber crops such as cotton-derived materials, jute (Corchorus sp.) and mesta (Hibiscus spp.) biomass have also been explored for bioethanol production [30-32]. The use of these feedstocks contributes to reducing the volume of waste generated in the textile industry. Recently, jute biomass has been considered as a promising feedstock for bioethanol production, in particular in India, where 1.8 billion $\mathrm{kg}$ of this biomass were produced in 2018-2019 [33].

\subsection{Municipal Solid Wastes}

The average amount of municipal solid waste (MSW) that one person generates in Europe is about $475 \mathrm{~kg}$ per year [34]. This number is constantly increasing due to the exponential growth of the global population, which is directly linked to an extensive consumption of energy and natural resources. MSW includes biodegradable garden waste, food and kitchen waste from households, offices, restaurants, wholesale, canteens, caterers, and retail premises, and comparable waste from food processing plants [6]. The organic fraction of MSW (OFMSW) is the largest fraction of MSW, representing $40-50 \%$ of the total dry matter content. OFMSW mainly contains carbohydrates (30-40\%), lipids (10-15\%), and proteins (5-15\%) (dry weight). Additionally, OFMSWs usually present variable contents of inert materials such as plastic, glass, and textiles, whose concentrations very much depend on the collection system used. The presence of a high amount of inert materials can provoke different technological problems and decrease the efficiency of the valorization process.

The characteristics and production rates of OFMSW are related to the sorting system, seasonality, population, dietary routines, and socio-economic conditions [35]. OFMW is envisaged as a challenging substrate due to its complex and heterogeneous nature. Moreno et al. [36] evaluated two different sorting systems for biowaste collection (source sorted (SSOFMW) and nonsorted (NSOFMW)) to use them as feedstock for the sequential production of bioethanol and biogas. The maximum ethanol concentrations achieved after subjecting these two substrates to a nonisothermal SSF processes were 51 and $26 \mathrm{~g} / \mathrm{L}$ for SSOFMW and NSOFMW, respectively, thus highlighting the importance of separating the biowaste at the source. 


\subsection{Plant Cell Wall Engineering}

Genetic engineering of lignocellulosic feedstocks represents an interesting strategy to ease the accessibility of carbohydrates during conversion processes. The complex chemical composition and structure of secondary cell walls create a physical barrier difficult to disrupt. Aiming to reduce this biomass recalcitrance, different alternatives have been proposed to genetically modify lignocellulosic feedstocks and improve conversion efficiencies. Furthermore, this strategy allows transferring of the tuned properties to future generations and makes the process more efficient along the years. Notwithstanding, the genetic changes introduced in these organisms my affect the plant cell growth and/or its developmental processes, which may negatively impact biomass yields [37].

Plants can be subjected to gene modification to improve the polymer synthesis in the cell wall (specifically cellulose), to reduce crystallinity of cellulose, and to modify the structure of the lignin polymer. Among these strategies, lignin modification has been directly targeted at reducing biomass recalcitrance. Modification of the lignin structure has been performed by altering the phenolic metabolism. Lignin polymer is formed by $p$-hydroxphenyl $(\mathrm{H})$, guaiacyl $(\mathrm{G})$, and syringyl $(\mathrm{S})$ units, which derive from the aforementioned $p$-coumaryl, coniferyl and sinapyl alcohols, respectively. The ratio between these units varies depending on tissue and plant species. For instance, lignins from gymnosperms usually contain a higher proportion of $\mathrm{G}$ units, while lignins in angiosperms are mainly composed of both $\mathrm{G}$ and $\mathrm{S}$ units [38].

The biosynthesis of monolignols involves several enzymes, which are potential targets for genetic engineering [39]. A key enzyme in the early steps of this biosynthetic pathway is 4-coumarate, CoA ligase (4CL), which catalyzes the conversion of $p$-coumaric acid to p-coumaroyl-CoA (intermediate metabolite in the phenylpropanoid pathway). By deleting the Pv4CL1 gene (which encodes 4CL enzyme), Park et al. [40] produced knock-out mutant switchgrass plants with an $8-30 \%$ reduction in the lignin content. Compared to control assays, these mutants increased the released of glucose and xylose by $7-11 \%$ and $23-32 \%$, respectively, without acid pretreatment.

In addition to modifying the lignin content, reducing the crystallinity of cellulose and the content of this polymer is also an important objective during plant engineering. In this context, Yang et al. [41] have investigated the overexpression of the PdDUF266A gene in Populus. DUF266 proteins are categorized as "not classified glycosyltransferases" (GTs) and might therefore play an essential role during the synthesis of polysaccharides. By overexpressing the PdDUF266A gene in Populus, the total cellulose content increased by $37.1 \%$, which improved the total sugar released during the subsequent saccharification process by $38 \%$.

In brief, genetic engineering of plant cell walls offers great possibilities for improving the efficiency of lignocellulose conversion processes within a bio-based economy perspective, although further research is needed to understand the full potential of these strategies and reduce the negative impact of such modifications.

\section{Pretreatment Technologies for the Effective Use of Lignocellulose}

Given the heterogeneous composition of lignocellulosic biomass, fractionation is the only way to make an effective and complete use of this resource. However, the intricate and highly compact structure of lignocellulose makes it difficult to get to the different components and separate them so they can be properly valorized. In this sense, the pretreatment is the set of operations aiming at disrupting the carbohydrate-lignin matrix, facilitating the access to, and recovery of, the valuable compounds.

\subsection{Types of Pretreatment}

Pretreatment technologies have been traditionally classified according to their driving force in physical, chemical, physicochemical, and biological methods [42-44]. This classification is becoming outdated, as it was conceived to be applied to unit operations and the scope and focus of the pretreatment have since changed [45]. Following this current, the 
present work establishes a discussion about types of pretreatment from different points of view, using nonexclusive categories.

\subsubsection{Conventional Pretreatments}

Conventional pretreatments represent the state of the art, they are robust, close to the concept of unit operation and the technology is well known and easy to implement $[46,47]$. Conventional pretreatment technologies that have been thoroughly described in the scientific literature commonly involve acid/base, water and steam [48]. These technologies are the most mature and the hydrothermal pretreatments (namely liquid hot water and steam explosion) are, especially, the basis of most of the processes used in demo/commercial plants $[49,50]$. For instance, the PROESA ${ }^{\circledR}$ technology (from Versalis company), relies on a steam-explosion-like pretreatment and it is currently used in the commercial-scale plant located at Crescentino (Italy), with a $22 \mathrm{kt} / \mathrm{y}$ biomass processing capacity [51]. Furthermore, Clariant's Sunliquid ${ }^{\circledR}$ technology has also reached the commercial scale, proposing a chemical-free hydrothermal pretreatment [52]. Conventional pretreatments focus on maximizing the conversion of sugars, and for this, harsh conditions are usually applied [53]. A drawback of using high temperatures and/or aggressive chemical agents is the degradation of carbohydrates contained in the biomass and the formation of inhibitory compounds for the hydrolysis and fermentation steps. Other disadvantages of conventional pretreatments are their high contribution to the overall cost of the process that has been estimated (up to $30 \%$ ) [54], and the problem of recycling and disposal of chemical catalysts if they are used $[43,49]$.

In spite of the time passed since their first applications, the conventional methods are still attracting research interest, either in combination with other treatments $[55,56]$ or as part of a biorefinery strategy [46].

\subsubsection{Advanced Pretreatments}

New technologies started to appear when the focus of the pretreatment changed from the cellulose fraction, exclusively, to the whole biomass, connecting with the biorefinery concept. In this new approach, all biomass components are important, and not only the quantity but also the quality of the products recovered is taken into account.

Advanced pretreatments are designed to overcome the limitations of conventional pretreatments. For this purpose, they employ novel solvents (i.e., super-critical fluids [57], ionic liquids (ILs) [58], deep eutectic solvents (DESs) [59], inorganic salts [60]), novel technologies (i.e., popping [61], gamma ray [62], electron beam irradiation [63]), novel process strategies such as milder operating conditions and/or higher solids content (i.e., low liquid ammonia [64], low-temperature hot water pretreatment [65]), or a combination of several principles (see Section 3.1.4). This type of pretreatment presents one or more advanced features such as being carried out at milder operation conditions, not producing inhibitors, low chemical usage and high specificity towards lignin or efficient fractionation $[54,66]$. However, most of these novel technologies have only been tested at the laboratory or semipilot scale, as seen in the previously referenced works, and therefore, there is not enough data to perform a consistent techno-economic evaluation [54].

Some advanced pretreatments are promising and have further development opportunities; for example, ILs and DESs are still the subject of intensive research and the efforts made until now have made possible to make significant progress in sustainability, security, price, and performance issues $[53,67]$. However, many other methods are not able to break through due to health or sustainability concerns, complex equipment, poor scalability or not showing a good enough performance, and the research interest eventually fades away.

\subsubsection{Integrated Pretreatments}

In these types of processes, also known as one-pot bioprocesses, pretreatment is coupled to at least a part of the bioconversion step (which includes enzymatic hydrolysis and fermentation) in the same reactor, with minimum conditioning of the pretreated biomass. 
Biological pretreatments are the most obvious candidates for one-pot processes. A combination of laccases, for lignin degradation, with cellulolytic and hemicellulolytic enzymes can be used to liberate free sugars ready for fermentation [68]. Sometimes, only microorganisms are used to pretreat the biomass [69], which connects with the idea of the consolidated bioprocessing (CBP) [43].

Mechanical pretreatments are especially suitable for developing integrated processes. At its simplest configuration, ball milling was used to directly pretreat biomass impregnated with hydrolytic enzymes [70]. Mechanocatalytic pretreatments combine ball milling with a catalyst (typically $\mathrm{H}_{2} \mathrm{SO}_{4}$ ) in solid-state to directly yield soluble sugars that could be subsequently fermented [71-73]. A more complex system is the bioextrusion process proposed by Duque et al. [74], which applies an alkaline catalyst and performs neutralization, filtration of the excess of liquid, and impregnation with enzymes in a process that could be carried out in a single step in one extrusion machine.

ILs are also the basis for many integrated pretreatments because of their effectiveness and the mild conditions at which the process is carried out. However, some ILs have an undesired degradation effect on enzymes, which hindered the coupling of the IL pretreatment with the saccharification step for years [75]. The use of compatible ILs [67,76] or the increase in the resistance of cellulases through immobilization [75] made the integration of pretreatment and bioconversion possible.

Integrated pretreatments have several advantages: the use of mild conditions results in no production of inhibitors and preservation of carbohydrates [70,74]. Furthermore, the absence of transfer operations minimizes mass losses and simplifies piping at the industrial scale, requiring less manual labor as well $[68,77]$. Other authors highlight the eco-friendly nature of integrated pretreatments, as they allegedly require less energy than conventional processes, use less chemicals and water and produce fewer wastes and/or undesired by-products $[70,71,78,79]$. Nevertheless, the use of milder conditions may result in a lower efficiency [80] due to the fact that using only one reactor makes one-pot pretreatments more oriented to single-product processes, as the recovery of various products from the final mash could be complex.

\subsubsection{Combined Pretreatments}

In the scientific literature, there are many terms to refer to mixtures of pretreatments (combined, two-step, sequential, hybrid). These words are usually employed indistinctly; however, to facilitate the discussion, in the present work the term "combined pretreatment" is used as the general expression, "two-step pretreatment" is employed for one type of pretreatment (same principle) applied twice at different conditions or with different reagents, "hybrid pretreatment" is used for the mixture of two or more different kinds of pretreatment (different principles), and "sequential" refers to the mode of application.

Combining more than one type of pretreatment is an interesting approach when the objective is to achieve a complete fractionation of the biomass, since the type and conditions of each pretreatment can be adapted to maximize the recovery of the different components $[66,81]$. In these types of configuration, biomass components are usually recovered separately in different streams.

Combined pretreatments seem to increase the efficiency of the process compared to the individual technologies [81,82]; they allow the obtention of high sugar yields with milder operation conditions and require lower solvent and enzyme amounts, thus improving the cost and sustainability of the final product [83-85]. However, Galbe and Wallberg [45] have some doubts about the real applicability of combined pretreatments because of their elevated costs and complexity.

\section{Two-Step Pretreatments}

Two-step steam explosion is a well-known process that has appeared in the scientific literature several times [86,87]. It consists of a first step carried out at low severity to hydrolyze the hemicellulosic sugars without degrading them. The pretreated solid is then 
submitted again to steam explosion at higher severity to enhance its enzymatic digestibility. Similarly, liquid hot water pretreatment can be performed in two steps to maximize sugar recovery $[88,89]$.

The most basic configuration for a two-step chemical pretreatment is to recover the hemicellulosic fraction through a low $\mathrm{pH}$ pretreatment and then apply an alkaline method to the remaining fiber to separate the lignin from the cellulose $[81,83,90]$.

Furthermore, a sequential biological pretreatment with two thermophilic microorganisms was reported to increase the ethanol production from food waste [69]. Another example of two-step biological pretreatment is the case of white-rot and brown-rot fungi, which preferentially degrade lignin and holocellulose, respectively, and create a strong synergy when applied to wheat straw sequentially [91].

Complicating things even more, hybrid pretreatments can also be applied in two steps. For instance, Kandasamy et al. [92] tested combinations of ultrasound, acid and alkali pretreatments on sugarcane bagasse, and obtained the highest ethanol concentration with the application of an acid plus ultrasound followed by an alkali plus ultrasound treatment.

\section{Hybrid Pretreatments}

When designing a hybrid pretreatment, it is important to attend to the compatibility of the technologies, otherwise, the costs will be too high [45]. Attending to this criterion, numerous combinations of similar types of pretreatment have been investigated.

For instance chemical methods can be coupled to mechanical [93-95] and physicochemical [96] pretreatments, or chemical reactants of different natures [97] can be used sequentially to improve the performance of the individual treatments.

Biological pretreatments also get along with chemical processes and have been used in combination with, for instance, deep eutectic solvents [98], or dilute acid pretreatment [99].

Combination of physical and physicochemical pretreatments is also possible, as the coupling of steam explosion and extrusion [55], or hot water and disc milling [56].

As illustrated in Table 2, combination of pretreatments can be really inventive; however, the viability of most of the proposed methods is yet to be proven at a large scale.

Finally, hybrid pretreatments can be also applied in two steps. For instance, Kandasamy et al. [92] tested combinations of ultrasound, acid, and alkali pretreatments on sugarcane bagasse, obtaining the highest ethanol concentration $(911 \mathrm{mg} / \mathrm{L})$ with the application of an acid plus ultrasound, followed by an alkali plus ultrasound treatment.

\subsection{Pretreatment Selection}

With such a variety of technologies, deciding which one is more adequate for each application is not an easy task, since lignocellulose pretreatment needs a specific solution for each case. To facilitate the decision, different criteria can be followed. At a laboratory research level, pretreatments are usually compared in terms of yield (either of the intermediate or of the final products) [45], but this is not always enough, as several technologies could be able to satisfactorily fractionate the same biomass $[47,100]$. Depending on the target of the process, additional information about the quality and properties of the obtained products could be needed to make a decision.

It is not unusual to find studies that compare the performance of several pretreatments using a single biomass as reference in the scientific literature [47,82,101-103]. Some of these studies have been summarized in Table 3 . 
Table 2. Selected examples of hybrid methods used to pretreat different lignocellulosic biomasses.

\section{Effects}

Feedstock

Chemical + mechanical

Poplar wood chips

Description of the Process (Best Conditions)

1. Pre-extraction of hemicellulosic sugars with $\mathrm{DA}\left(1 \% w / w \mathrm{H}_{2} \mathrm{SO}_{4}, \mathrm{~L} / \mathrm{S}=10,150{ }^{\circ} \mathrm{C}\right)$.

2. Chemical treatment with $\mathrm{NaOH}(3 \% w / w)+$ $\mathrm{Na}_{2} \mathrm{SO}_{3}(4 \% w / w)$ at $80{ }^{\circ} \mathrm{C}, 30 \mathrm{~min}$.

3. Mechanical refining by pressurized refining followed by disk refining twice.
Main Findings

Reference

- Combined pretreatment enhanced the glucose yield compared to only DA (max. 93\%).

- Delignification, increase in SSA and increase in fines content were the mechanisms that had a significant positive impact on enzymatic digestibility.

- Combined pretreatment increased the glucose and xylose yield compared to the single pretreatments (max. $78 \%$ glucan conversion and $40 \%$ xylan conversion).

Chemical + mechanical $\quad$ Corn straw ball milling (140 rad/s, $8 \mathrm{~min})$

treatment with $20 \% w / w \mathrm{NaOH} / \mathrm{dry}$ matter, $\mathrm{L} / \mathrm{S}=1$, at $130{ }^{\circ} \mathrm{C}$ for $90 \mathrm{~min}$, followed by extrusion with addition of $\mathrm{H}_{2} \mathrm{SO}_{4}$ until $\mathrm{pH} 5$, at $100{ }^{\circ} \mathrm{C}$ and $150 \mathrm{rpm}$.
Chemical + thermo-mechanica

Eucalyptus grandis wood

- $\quad$ Cellulase added could be reduced by 10 times (until 1.5 FPU/g straw) without affecting the sugar yields.

- Combined pretreatment increased by $13 \%$ the glucan conversion and $44 \%$ the xylan conversion obtained only with the alkaline

Acid treatment with $10.5 \% w / w \mathrm{H}_{2} \mathrm{SO}_{4}$ / dry matter, $33 \% w / w$ solids and at $128^{\circ} \mathrm{C}$, followed by SE at $195{ }^{\circ} \mathrm{C}$ for $5 \mathrm{~min}$. 
Table 2. Cont

\begin{tabular}{|c|c|c|c|c|}
\hline Effects & Feedstock & Description of the Process (Best Conditions) & Main Findings & Reference \\
\hline Biological + chemical & Bamboo shoot shell & $\begin{array}{l}\text { Galactomyces sp. CCZU11- } 1 \text { at } 30^{\circ} \mathrm{C} \text { for } 3 \text { days, } \\
\text { followed by DES choline chloride: oxalic acid } \\
(\mathrm{ChCl}: \mathrm{OA}, 1 \mathrm{~mol} / 2 \mathrm{~mol}) \text { extraction at } 120^{\circ} \mathrm{C} \\
\text { for } 1.5 \mathrm{~h} \text {. }\end{array}$ & $\begin{array}{l}\text { - } \quad \text { Xylan and lignin removal. } \\
\text { - } \quad 74.1 \% \text { hydrolysis yield of glucan. }\end{array}$ & [98] \\
\hline Biological + chemical & Olive tree biomass & $\begin{array}{l}\text { Solid state fermentation with Irpex lacteus for } \\
28 \text { days, followed by DA treatment with } 2 \% \text { w/v } \\
\mathrm{H}_{2} \mathrm{SO}_{4} \text { at } 130{ }^{\circ} \mathrm{C} \text { and } 90 \text { min. }\end{array}$ & $\begin{array}{l}\text { - } 34 \% \text { increase in enzymatic hydrolysis yield } \\
\text { compared to DA only. } \\
\text { - Overall sugar yield of } 51 \% \text {. }\end{array}$ & [99] \\
\hline $\begin{array}{l}\text { Physicochemical + } \\
\text { thermo-mechanical }\end{array}$ & Barley straw & $\begin{array}{l}\text { SE at } 180{ }^{\circ} \mathrm{C}, 3.5 \mathrm{~min} \text {, preimpregnation of } \mathrm{BS} \text { with } \\
10 \mathrm{mg} \mathrm{H} \mathrm{HO}_{4} / \mathrm{g} \text { biomass. Then, } \mathrm{AE} \text { at } 100^{\circ} \mathrm{C} \text {, } \\
1 \mathrm{~min}, 80 \mathrm{mg} \mathrm{NaOH} / \mathrm{g} \text { BS. }\end{array}$ & $\begin{array}{l}\text { - } 40 \% \text { increase in ethanol production of } \mathrm{SE}+ \\
\text { AE compared to only SE. } \\
\text { Fractionation into glucose, xylose and lignin } \\
\text { streams with high recoveries. }\end{array}$ & [55] \\
\hline Physicochemical + mechanical & Corn stover & $\begin{array}{l}\text { LHW at } 20 \% \text { solids, } 180{ }^{\circ} \mathrm{C} \text { and } 4 \mathrm{~min} \text {, followed by } \\
\mathrm{DM} \text { with minimal gap, } 89 \mathrm{rpm}, 9 \text { cycles.DA with } \\
1 \% w / w \mathrm{H}_{2} \mathrm{SO}_{4} \text { at } 150{ }^{\circ} \mathrm{C} \text { for } 4 \text { min followed by } \\
\mathrm{DM} \text { (same conditions). }\end{array}$ & $\begin{array}{l}\text { - } \quad \text { LHW + DM: } \\
\text { 89\% increase in glucan hydrolysis and 134\% } \\
\text { increase in xylan hydrolysis compared to } \\
\text { only LHW. } \\
\text { - } \\
\text { Reduction in energy consumption of DM } \\
\text { by } 63 \% \text {. } \\
\text { DA + DM: } \\
\text { - } \% \text { increase in glucan hydrolysis and } 5 \% \\
\text { increase in xylan hydrolysis compared to } \\
\text { LHW + DM. } \\
\text { Need for corrosion resistant reactor and } \\
\text { postprocessing of the pretreated substrate. }\end{array}$ & [56] \\
\hline
\end{tabular}

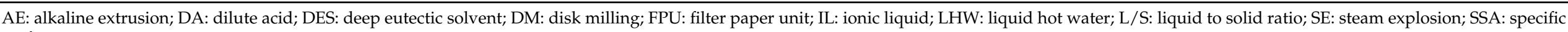
surface area. 
Table 3. Compilation of comparisons among different pretreatment methods.

Feedstock Pretreatments and Conditions

LHW $\left(175^{\circ} \mathrm{C}, 2\right.$ h, L/S 10:1, 12 bar $)$ MWAC $\left(210{ }^{\circ} \mathrm{C}, 2 \mathrm{~min}, 2 \% \mathrm{H}_{2} \mathrm{SO}_{4}\right)$

Cotton stalks AIK $\left(10 \% \mathrm{NaOH}, 121^{\circ} \mathrm{C}, 15 \mathrm{~min}\right)$ OS (formic acid $+\mathrm{H}_{2} \mathrm{O}_{2}, 2 \%, 80^{\circ} \mathrm{C}$ )

$$
\text { - Hybrid OS-LHW pretreatment }
$$

- $\quad$ DA $\left(1.6 \% \mathrm{H}_{2} \mathrm{SO}_{4}, 120^{\circ} \mathrm{C}, 20 \mathrm{~min}\right)$

SE (50\% moisture, $\left.121^{\circ} \mathrm{C}, 30 \mathrm{~min}\right)$

AFEX $\left(70-120^{\circ} \mathrm{C}, 0.2-2 \mathrm{~mL}\right.$ water $/ \mathrm{g}$

dry biomass, 1-30 $\mathrm{min}$ )

- $\quad$ Concentrated PA $\left(8.5 \mathrm{~g} \mathrm{H}_{3} \mathrm{PO}_{4} / \mathrm{g}\right.$ dry

biomass, $50{ }^{\circ} \mathrm{C}, 1 \mathrm{~h}+24 \mathrm{~g}$ acetone/g

- $\quad$ AAPP $(80 \mathrm{kV}, 4 \mathrm{~min})$

- $\quad \mathrm{FC}\left(0.8 \mathrm{~g} \mathrm{FeCL}_{3} / \mathrm{g}\right.$ dry biomass,

$\left.120^{\circ} \mathrm{C}, 30 \mathrm{~min}\right)$

- $\quad$ OS (ethanol 50\%-water 70\% + 1\%w/w

$\left.\mathrm{H}_{2} \mathrm{SO}_{4}, 120{ }^{\circ} \mathrm{C}, 30 \mathrm{~min}\right)$

- $\quad \operatorname{MWALK}(800 \mathrm{~W}, 30 \mathrm{~s})$

- $\quad$ Hybrid PA-AFEX pretreatment
Composition Enzymatic digestibility Ethanol production

Variables Studied

Main Results

Reference

- All pretreatments resulted in cellulose concentration.

- The hemicellulose content of the pretreated substrates decreased for all pretreatments except for ALK.

- Hybrid, OS and ALK pretreatments caused delignification of the pretreated substrate.

- Hybrid pretreatment had the highest enzymatic digestibility and ethanol production; however, the glucose recovery in the pretreated substrate was the lowest among the different methods.

- $\quad$ Most of the pretreatments (except for OS, AFEX and SE) concentrated cellulose in the pretreated substrate.

- Most of the pretreatments reduced the total content of lignin in the pretreated substrate.

- Only OS produced a significant amount of organic acids (furfural) in the liquor.

- The structure was altered and chemical bonds were broken in all pretreatments.

Composition Physical structure Crystallinity Thermal behavior Enzymatic digestibility

MWALK, AAPP and OS were the methods that conserved more hemicellulose in the pretreated substrate.

- Crystallinity of pretreated substrates increased with all pretreatments.

- $\quad$ All of the pretreatments increased the enzymatic digestibility of the pretreated substrate.

- The hybrid pretreatment showed the highest cellulose concentration, delignification, crystallinity and enzymatic digestibility.

- $\quad$ OS resulted in the highest hemicellulose and lignin extraction and highest glucose recovery.

- $\quad$ SE pretreated rye straw had the highest enzymatic digestibility, but lowest $\mathrm{C} 5$ recovery in the liquor and resulted in a single lignin stream.

Rye straw $\quad-\quad \mathrm{SE}\left(200^{\circ} \mathrm{C}, 20 \mathrm{~min}\right)$

LHW $\left(200^{\circ} \mathrm{C}, 45 \mathrm{~min}\right)$
Enzymatic digestibility Composition Lignin 
Table 3. Cont

\section{Feedstock}

DA $\left(1 \% w / w \mathrm{H}_{2} \mathrm{SO}_{4}, 10 \%\right.$ solids

loading, $140{ }^{\circ} \mathrm{C}, 40 \mathrm{~min}$ )

- $\quad \mathrm{SO}_{2} \mathrm{SE}\left(5 \% w / w \mathrm{SO}_{2}, 10 \%\right.$ solids loading, $180^{\circ} \mathrm{C}, 10 \mathrm{~min}$ )

- $\quad$ LHW (15\% solids loading, $200{ }^{\circ} \mathrm{C}$

Switchgrass $10 \mathrm{~min}$ )

- $\quad \operatorname{AFEX}\left(2 \mathrm{~g} \mathrm{H}_{2} \mathrm{O} / \mathrm{g}\right.$ biomass, $1.5 \mathrm{~g}$ $\mathrm{NH}_{3} / \mathrm{g}$ biomass, $140{ }^{\circ} \mathrm{C}, 30 \mathrm{~min}$ )

- $\quad$ SAA $\left(1.3 \mathrm{~g} \mathrm{NH}_{4} \mathrm{OH} / \mathrm{g}\right.$ biomass, $\left.160^{\circ} \mathrm{C}, 60 \mathrm{~min}\right)$

- $\quad$ Lime $\left(\mathrm{Ca}(\mathrm{OH})_{2}\right.$ :biomass $=1 ; 15 \mathrm{~g}$ $\mathrm{H}_{2} \mathrm{O} / \mathrm{g}$ biomass, $120^{\circ} \mathrm{C}, 4 \mathrm{~h}$ )
Variables Studied

Main Results

Reference

- The highest lignin removal was attained with SAA and lime pretreatments.

- Xylan removal was higher for $\mathrm{DA}, \mathrm{SO}_{2} \mathrm{SE}$ and LHW pretreatments.

Enzymatic digestibility

Composition

Physical structure

- Deacetylation was high for all pretreatments except for AFEX

- $\quad$ Enzymatic digestibility $>70 \%$ was obtained at lower enzyme load in DA, $\mathrm{SO}_{2} \mathrm{SE}$ and LHW pretreated biomass than in AFEX or SAA.

- Most of the basic structure was intact after the pretreatments, although some impacts that differed among methods could be seen.

- $\quad$ IL (1-ethyl-3-methylimidazolium acetate, $15 \% w / w$ biomass loading $\left.140{ }^{\circ} \mathrm{C}, 3 \mathrm{~h}\right)$

Corn stover
- $\quad \operatorname{DA}\left(0.5 \% w / w \mathrm{H}_{2} \mathrm{SO}_{4}, 10 \% w / w\right.$ solids loading, $160{ }^{\circ} \mathrm{C}, 20 \mathrm{~min}$ )

AFEX $\left(\mathrm{NH}_{3}\right.$ :biomass $=1,60 \%$ moisture, $140{ }^{\circ} \mathrm{C}, 15 \mathrm{~min}$ )

\section{Crystallinity}

Roughness

Surface Morphology

Thermochemical properties

Chemical structure

Lignin depolymerization
- $\quad$ Biomass pretreated by IL and AFEX was less thermally stable than DA.

- IL and AFEX caused great hemicellulose removal.

- DA pretreated biomass showed $50 \%$ re-condensed lignin.

- IL resulted in the highest lignin de-polymerization compared to DA and AFEX

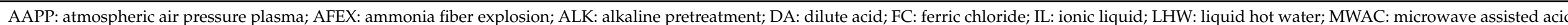

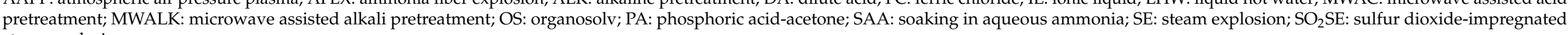
steam explosion. 
Apart from the effects on the biomass, there are other aspects to take into account for evaluating a pretreatment such as the mass balance of the process (reduced mass losses and/or sugar degradation), the possible formation of inhibitors, the flexibility towards the feedstock, the material and energy requirements or the upscaling possibilities [43]. Moreover, pretreatment is usually an energy-intensive step with high associated costs and a great impact on all the upstream and downstream operations [100]. Faced with this complex scenario, the best selection tools are those that take the whole process and its context (i.e., the location of the plant, if there are some pre-existing facilities, etc.) into consideration. The techno-economic analysis or the life cycle assessment are two of the most common methodologies $[104,105]$, but there are other holistic approaches such as emergy, energy or exergy analyses [106], green indexes [3] and multiobjective optimization [104,107]. The weak point of all these technologies is the amount of information that they need, since the quality of the analysis depends heavily on the accuracy and reliability of the data used and the assumptions made. In this regard, most of the analyses of novel systems (where experimental data is scarce) rely on the use of process simulation software [104].

\subsection{Perspectives for the Investigation of Biomass Pretreatment}

Every year several reviews are published summarizing the features of the main pretreatments and updating the list with the latest novelties $[45,50,53,54,66]$. New pretreatment methods (more sophisticated, greener, with better performances) are continuously brought to light. Still, the essential problem remains unsolved: up to the present, no "perfect" universal pretreatment has been found $[45,66]$. Indeed, that is not likely to happen, since biomass is a heterogeneous category that contains materials sufficiently distinct among them to make it necessary to approach the problem in different ways. The particular characteristics of the biomass and the targeted products help to establish the framework of the process, but the economy and environmental impact are key issues that impose constraints on the feasibility of the chosen path. In this regard, decision tools that use a holistic view of the processes are essential, but for them to be accurate a huge amount of information is needed, including exhaustive experimental data from laboratory and, better yet, pilot assays. Hence, intensive research in the field of biomass pretreatment will predictably continue to be a relevant topic in the coming years.

\section{Advances in Enzymatic Preparations and Fermentative Microorganisms for Robust Industrial Processes}

Pretreated biomass still needs to undergo further processing in order to fully convert the structural carbohydrates into ethanol. Cellulose and hemicellulose are required to be hydrolyzed into monomeric fermentable sugars (glucose and xylose are major representatives, respectively), which are afterwards fermented by microorganisms into the desired product.

\subsection{Enhanced Enzymatic Hydrolysis for an Increased Release of Sugars}

Hydrolysis can be either chemical (using mineral acids such as $\mathrm{H}_{2} \mathrm{SO}_{4}$ or $\mathrm{HCl}$ ) or enzymatic. The former causes an almost complete glucose liberation from the cellulose chain though promoting undesired hemicellulose degradation and formation of inhibitors, while the latter is carried out under milder conditions and with a lower environmental impact [108]. Due to the associated problems that arise when using acids $[109,110]$, enzymatic hydrolysis is considered to be the preferred technique for the conversion of biomass into high value-added products and it will be the focus of this section.

Cellulose is broken down into monomeric glucose by the integrated action of a series of enzymes known as cellulases: cellobiohydrolases, endoglucanases, and glucosidases. Figure 1 shows a simple schematic representation of the synergistic work of these enzymes for the liberation of glucose. 


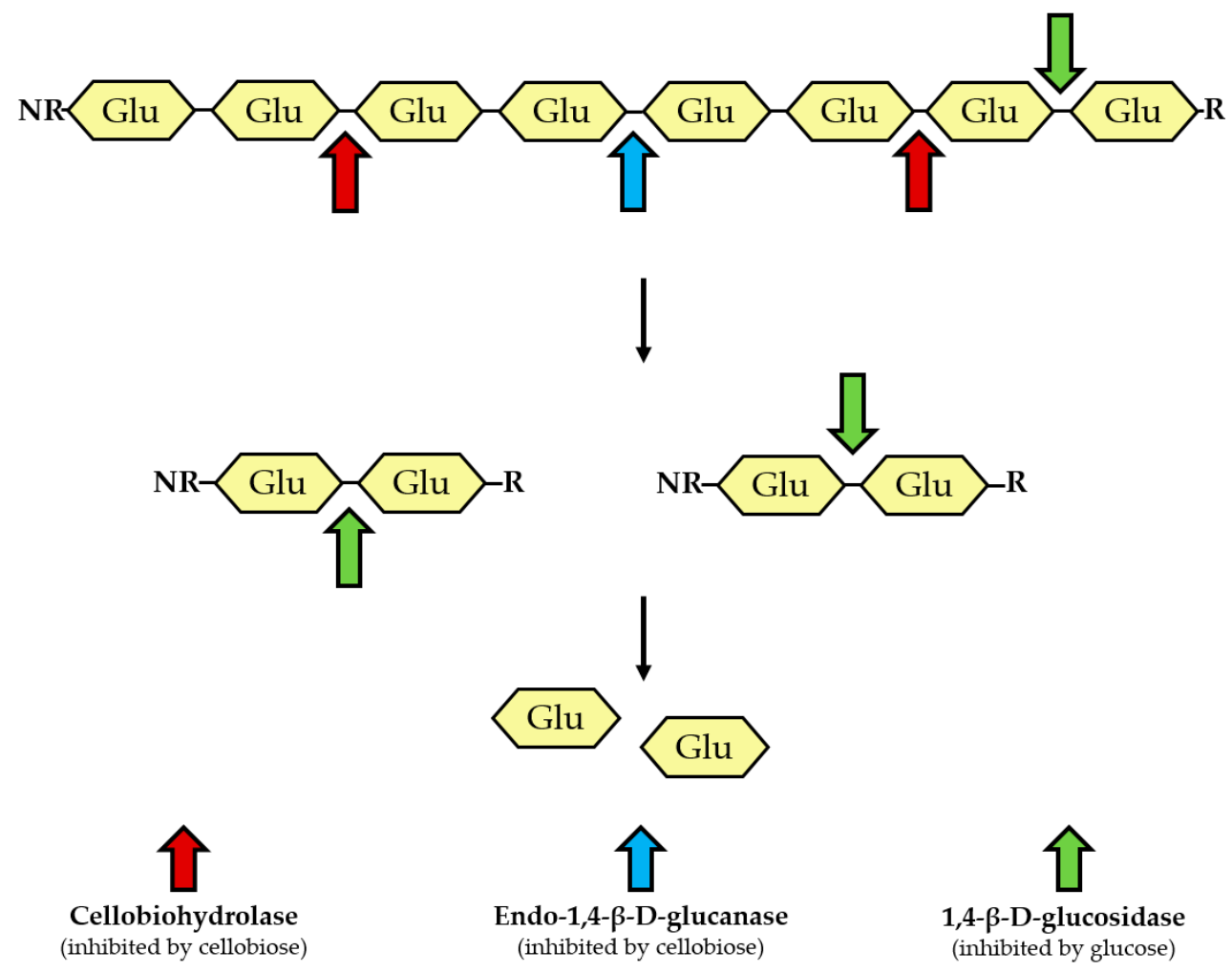

Figure 1. Simple schematic representation of the action of cellulases for glucose liberation from cellulose. R: reducing end; NR: nonreducing end; Glu: glucose unit; CBH: cellobiohydrolase. Adapted from [111].

Glucose is obtained from the combined action of these enzymes on the cellulosic polymer. Cellobiohydrolases (exo-1,4- $\beta$-D-glucanase, EC 3.2.1.91) go along the linear cellulose chain separating units of cellobiose from the ends. Endoglucanases (endo-1,4- $\beta$-Dglucanase, EC 3.2.1.4) randomly hydrolyze internal bonds in order to increase the number of chain ends for the action of cellobiohydrolases. Finally, glucosidases (1,4- $\beta$-D-glucosidases, EC 3.2.1.74) break down the disaccharides obtained by the cellobiohydrolases into two units of glucose [112]. Product-inhibition is present in this process: the first two enzymes are inhibited by cellobiose, while glucosidases are inhibited by glucose itself [112,113]. This, along with other issues concerning enzymes, results in a low efficiency of the enzymatic system, thus rendering it a major contributor to the elevated cost of ethanol production - up to $28 \%$ of the final price [114]. Cellulose hydrolysis, as shown in Figure 1, has become a widely established process over recent years and enzymatic preparations containing cellulolytic enzymes are broadly optimized, shifting the research focus towards other aspects on the process such as process configurations, use of additives or enhancing the synergistic effect with other relevant enzymes.

Over recent years, great focus has been placed on the investigation of novel process schemes and enzymatic preparations for solving the problems that arise during this step. The review of da Silva et al. [113] was centered on high-solids (over $15 \% w / w$ ) enzymatic hydrolysis, which is considered to be crucial for an economically feasible ethanol production process. They noted the main limiting factors of the process to be the effect of water constraint, presence of inhibitors (sugars and other products derived from pretreatment) as well as of lignin and pseudo-lignin, and mass transfer limitations. Jørgensen and Pinelo [114] carried out an extensive review on enzyme recycling as a way to increase biocatalytic productivity and thus reduce the overall use of enzymes, addressing issues such as enzyme stability and its adsorption (and desorption) to biomass.

Several of the aspects to be improved on enzymatic hydrolysis can be addressed by means of novel enzymatic preparations or new formulations able to overcome the drawbacks that arise in the process not related to its configuration. In this sense, the private 
sector and academia have made great efforts to boost the performance of enzymes and their resistance to inhibitors by investigating the supplementation of chemicals, enzymes and/or proteins [115]. Notable research has been carried out on the use of additives to traditional enzymes aiming to improve their productivity. The supplementation of certain additives helps reduce nonproductive binding of enzymes to lignin instead of cellulose, a mechanism thoroughly described by Eriksson et al. [116]. Tween 80 is one of the most-studied additives on enzymatic hydrolysis. Parnthong et al. [117] studied the addition of this nonionic surfactant on the hydrolysis of palm fruit bunch and palm fruit residue with commercial cellulases from Trichoderma reesei: an addition of $0.25 \%(w / v)$ of Tween 80 provided an increase of $55 \%$ in sugar concentration for the bunch, and an addition of $0.5 \%(w / v)$ increased the sugar concentration by $39 \%$ compared to the case without surfactant for the residue. They attributed the need for higher additive to the higher lignin content, while addressing a threshold value of $1 \%(w / v)$ Tween 80 addition after which the enzyme is solubilized due to the micellar effect. Luo et al. [118] studied several additives besides the aforementioned Tween 80-namely, soy protein extract (SP), bovine serum albumin (BSA), and lignosulfonate, on the enzymatic hydrolysis of bamboo and wood substrates with Celluclast $1.5 \mathrm{~L}$. The addition of $80 \mathrm{mg} \mathrm{SP} / \mathrm{g}$ glucan promoted an almost two-fold increase in enzymatic conversion of eucalyptus biomass (from $54 \%$ to $94 \%$ ); this additive was considered superior to BSA, given its highly expensive cost, and Tween 80, given its associated problem regarding downstream processing, while lignosulfonate resulted in no significant differences when compared to the others. Rocha-Martin et al. [119] added polyethylene glycol (PEG4000) to the hydrolysis of pretreated corn stover and sugar cane straw and compared its improvement to the one provided by using different surfactants (Tween 80 among others) and BSA. PEG4000 resulted in a slightly increased glucose release when compared to the other additives, and the authors comprehensively analyzed the interaction of said polymer on the enzyme-biomass complex in order to understand its effect. Among the advantages described, PEG4000 aided in lowering liquefaction times considerably and thus the mixing requirements. Baral et al. [120] studied another PEG variant, PEG6000, as an additive in the hydrolysis of sugarcane bagasse with Cellic ${ }^{\circledR} \mathrm{CTec}$, reducing the reaction time and facilitating desorption of more than $55 \%$ of the loaded protein from lignin-rich biomass.

The use of additives for hydrolysis enhancement is not limited to surfactants or polymers, but also to additional enzymes that may contribute to a complete disruption of the carbohydrates. Yang et al. [121] supplemented a mixture of commercial cellulose (Celluclast 1.5 L and Novozymes 188) with additional endo-1,4- $\beta$-xylanase, PEG4000, and Tween 80 , for the hydrolysis of barley straw. Addition of xylanase alone did not provide any significant improvement, while the combined addition of xylanase and PEG4000 resulted in the highest glucose and xylose yields ( $86.9 \%$ and $70.2 \%$, respectively). Similar additives and enzymes were studied by Li et al. [122] for the hydrolysis of moso bamboo biomass. Addition of xylanase alone to a mixture of cellulases increased glucose yield to a higher extent than adding only Tween 80 ( $63.8 \%$ vs. 59.7\%), while the yield reached up to almost $70 \%$ when combining both. Xylanase addition to commercial enzymes is a common practice for the liberation of sugars. In fact, most commercial cellulases already contain a fraction of xylanase activity [123]. Supplementation of further xylanase on these cocktails has proven to be effective in improving the digestibility of cellulose, as the disruption of the cellulose with hemicellulose union improves the porosity of the former, thus aiding the access of cellulases to the polymer [124]. Cintra et al. [125] supplemented the commercial cellulase Accelerase 1500 with different recombinant hemicellulolytic enzymes for the hydrolysis of steam-exploded sugarcane bagasse. By combining these enzymatic preparations, a $14.6 \%$ increase in glucose release was attained, but the highest improvement (50\% increase compared to the cellulase alone) was achieved when carrying out a sequential hydrolysis, first with the recombinant hemicellulases followed by the commercial cellulase. Pengilly et al. [126] studied the enzymatic hydrolysis of triticale straw with commercial cellulases Spezyme CP and Cellic ${ }^{\circledR}$ CTec2 supplemented with 
the commercial hemicellulase Cellic ${ }^{\circledR}$ HTec2, along with Novozyme 188 for additional $\beta$-glucosidase activity. Optimization of the enzymes with time showed that reaction times increased with higher enzyme dosages as expected, and the supplementation of the hemicellulase increased glucan conversion from $51.94 \%$ to $80.74 \%$. However, the statistical analysis carried out by the authors pointed out that the interaction between cellulase and hemicellulase was not statistically significant, suggesting no synergistic effect between these activities.

Along with xylanases, another family of enzymes that has proven to be of great use in the hydrolysis of cellulosic substrates are lytic polysaccharide mono-oxygenases (LPMOs). LPMOs are a group of oxidative enzymes secreted by fungi. LPMOs have been recently discovered and patented by the Danish company Novozymes, which includes these activities in many of their commercial enzymatic cocktails [127]. The specific action mechanisms of LPMOs on the lignocellulosic complex have been thoroughly described by Müller et al. [128]. These enzymes boost the effectivity of cellulases by destabilizing glycosidic bonds in the carbohydrate due to the redox reactions associated with the copper ion present in the enzyme [128,129]. Recent research regarding LPMOs has focused on the process conditions that affect hydrolysis concerning aspects related to the aforementioned enzymes, such as, for instance, how prior pretreatment methods may affect the accessibility of enzymes to the carbohydrates. Rodríguez-Zúñiga et al. [130] evaluated the effect that pretreatment has on the action of LPMOs with several biomasses and Cellic ${ }^{\circledR} \mathrm{CTec} 2$ as an enzymatic cocktail (reportedly containing a significant content of the enzymes of interest by measuring the content of gluconic acid during hydrolysis), reporting a higher cellulose oxidation for biomasses pretreated by hydrothermal methods compared to organosolv and alkaline technologies. Enzymatic cocktails containing LPMOs are known to be susceptible to the presence of oxygen, as determined by Scott et al. [131]; the stability of Cellic ${ }^{\circledR}$ CTec3 for the hydrolysis of steam-exploded wheat straw increased when working under oxygendeprived conditions, but its efficiency was considerably reduced. The harmful effect that oxidative reactions had on the enzymatic mixture was alleviated by the authors by adding catalase, increasing the enzyme half-life without affecting the catalytic rate. LPMOs have been successfully produced by a variety of microorganisms, namely Aspergillus terreus [132], Talaromyces cellulolyticus [133] or Geotrichum candidum [134], among many others including GMOs; however, further deepening on the synergistic effect with traditional cellulases is required in order to fully optimize their action.

\subsection{Improving Microbial Performance for Ethanol Production}

The preparation of optimized enzymatic formulations, including the use of additives and supplementation of other functional enzymes apart from cellulases, is crucial for enhancing the liberation of sugars from lignocellulose. Fermentation of these sugars into ethanol can also be enhanced by looking at the microorganisms that carry out said bioprocess. Dien et al. [135] listed the main relevant features that a fermentative ethanolproducing microorganism requires for a robust industrial production: ethanol yield higher than $90 \%$, product tolerance no less than $40 \mathrm{~g} / \mathrm{L}$, and productivity of $1 \mathrm{~g} /(\mathrm{L} \cdot \mathrm{h})$, being a robust grower with simple growth requirements, ability to grow in undiluted hydrolysates with resistance to inhibitors, and being able to grow under acidic $\mathrm{pH}$ and high temperatures. The most common microorganisms used for the production of bioethanol are the yeast Saccharomyces cerevisiae and the bacteria Zymomonas mobilis, the former being the sole producer of $1 G$ ethanol [136]. However, no wild strains of these microorganisms are able to ferment pentoses. As xylose is a major component in the hemicellulosic fraction of biomass, advances in research are focusing on metabolic engineering for common fermenters to be able to properly convert xylose into ethanol. For instance, modification of S. cerevisiae for pentose consumption was extensively reviewed by Liu et al. [136] and Ruchala et al. [137]. Glucose and xylose cofermenting strains of S. cerevisiae are already being commercialized and used at the research level for the production of ethanol from lignocellulosic feedstocks utilizing both sugars coming from cellulose and hemicellulose 
polymers: these include XyloFerm ${ }^{\circledR}$, developed by Lallemand (Duluth, GA, USA) and Taurus Energy (Göteborg, Sweden) [138], Cellux ${ }^{\mathrm{TM}}$, developed by Leaf by Lessafre (Cedex, France) [139], and C5 FUEL ${ }^{\mathrm{TM}}$, developed by Mascoma (Lebanon, NH, USA) and Lallemand (Duluth, GA, USA) [140].

The research for fermenting microorganisms keeps moving beyond S. cerevisiae. Ruchala et al. [137] summarized the most recent advances in the modification of several yeasts: for S. cerevisiae, the biggest efforts were made on the expression of xylose catabolism into ethanol. On the other hand, S. stipitis is a known xylose fermenter, though with several drawbacks which make this yeast less robust compared to $S$. cerevisiae. The authors compiled advances on its modification aiming at reducing its main handicaps: low product tolerance, inhibition by the presence of glucose, and a strictly aerobic metabolism. The lower tolerance of these microbial strains to the inhibitory compounds present in these substrates makes it necessary to increase the robustness of the fermentative microorganisms. This can be performed by subjecting, for example, the fermentative microorganism to an adaptive laboratory evolutionary experiment. Using this strategy, Pereira et al. [27] increased the tolerance of S. stipitis to the inhibitors present in a hardwood SSL when compared to the parental strain, thus allowing an increase in the ethanol conversion efficiency from $26 \%$ to $32 \%$. Finally, Ogatea polymorpha (formerly Hansenula polymorpha) was outlined as a notable thermotolerant (up to $50{ }^{\circ} \mathrm{C}$ ) yeast capable of fermenting most of the sugars present in structural carbohydrates bar galactose and arabinose [137]. Its thermotolerance is considered to be a favorable characteristic for use in SSF, as the optimal temperature for cellulolytic enzymes is typically $50{ }^{\circ} \mathrm{C}$. Modification of said strain is focused on improving further its tolerance to ethanol and increasing the productivity of ethanol from xylose. Other relevant microorganisms that have been studied in recent years include Debaromyces hansenii [141], Kluyveromyces marxianus [142,143], Wickerhamomyces anomalus [144] or several species of the genus Candida [145]. Oshoma et al. [146] screened several Saccharomyces species besides $S$. cerevisiae for their tolerance to inhibitors in bioethanol production: Saccharomyces arboricus was noted as a potential producer tolerant to formic acid with similar levels of product formation-9.91 g/L from S. arboricus, 2.3319 against $10.20 \mathrm{~g} / \mathrm{L}$ from S. cerevisiae NCYC2592 at a formic acid concentration of $40 \mathrm{mM}$. Mukherjee et al. [147] carried out an extensive study on up to 232 nonconventional yeast species for their tolerance to inhibitors and other stressful conditions. Apart from the commercial S. cerevisiae strain Ethanol Red ${ }^{\circledR}$, the authors obtained the best results for Pichia kudriavzevii. The ethanol titers reached with this yeast $(25.53 \mathrm{~g} / \mathrm{L})$ strain are close to that of the commercial yeast $(27.20 \mathrm{~g} / \mathrm{L})$ but exhibited higher thermotolerance (up to $45^{\circ} \mathrm{C}$ ) and tolerance to acetic acid $(56 \%$ of the theoretical ethanol yield during fermentation with $0.5 \% v / v$ acetic acid). In general, all these works reach similar conclusions: the search for alternative fermenting microorganisms can be fruitful not only for their potential use as industrial strains themselves, but also for the introduction of their favorable traits into the traditional S. cerevisiae through metabolic engineering for a more robust bioethanol production.

While innovations in both enzymatic formulations and novel fermenting microorganisms are certainly relevant, it is also worth focusing on the synergistic improvements affecting both processes. Progress is being made with regard to integrating hydrolysis and fermentation steps (SSF) or even further integration with enzyme production (CBP) [148]. It is important to optimize all factors involved so that the different steps, with different optimal conditions, can be carried out at their optimums. Drawbacks cited in SSF processes are (a) the disparity in suitable temperatures being $50{ }^{\circ} \mathrm{C}$ for enzymatic hydrolysis but $30^{\circ} \mathrm{C}$ for yeast fermentation (described above), (b) ethanol being an inhibitor for common xylanases in processes where both hexoses and pentoses are to be fermented [149], or (c) LPMOs causing competition of available oxygen between LPMOs and yeast [150]. Strategies such as the use of thermotolerant microorganisms, the discovery of new xylanolytic enzymes, and/or the use of $\mathrm{H}_{2} \mathrm{O}_{2}$ as an oxidizing agent have been studied to overcome these challenges. Thermotolerance of the fermenting microorganism is a trait commonly searched for as previously described. New xylanases obtained from Emerciella nidulans [151] 
or marine bacteria Acinetobacter johnsonii [152] are being developed that not only show lower inhibition to ethanol, but a higher activity in its presence. Recent studies suggest that using $\mathrm{H}_{2} \mathrm{O}_{2}$ as an oxidizing agent instead of oxygen in anaerobic SSF processes could work as a solution for LPMO competition with microorganisms, as long as the peroxide concentration is low enough so that the microorganism does not suffer inhibition [153].

To sum up, recent research on enzymatic hydrolysis and fermentation improvements for a robust bioethanol production will be crucial for improving productivity and thus reducing operational costs, especially in the case of hydrolysis which is known to be the most cost-intensive step in current processes. The use of surfactants as additives for cellulases along with supplementation of other enzymes such as xylanases or LPMOs has been proven to be an effective way of increasing the digestibility of structural carbohydrates. Genetic modification of $S$. cerevisiae, as well as of other notable microorganisms, results in enhanced fermentations, granting them the capability to aptly ferment other abundant monomers such as xylose and resist higher temperatures more suitable for SSF processes. These improvements combined will aid sustainable ethanol production from lignocellulose in a more efficient manner, along with other aspects gathered throughout this review.

\section{Biorefinery Strategies for Contributing to Cost Reduction and Sustainability Improvement of Bioethanol Production}

In recent decades, the use of nonedible lignocellulosic biomass sources such as agricultural and forest residues, dedicated energy crops, and industrial residues for nonfood applications has been mostly addressed from a bioenergy/biofuel-based approach. In this context, diverse biomass to biofuel conversion technologies have been developed using mostly chemical, thermochemical, and biochemical processes, which have reached a different degree of implementation and development [154,155]. Among them, the conversion of lignocellulosic materials to fuel ethanol through the biochemical pathway based in pretreatment, enzymatic hydrolysis, and fermentation has been one of the most researched, as discussed in previous sections. As a consequence of the intense R\&D effort, there are currently several demonstration/first-of-a-kind commercial scale plants close to commercial operation and some new plants are being built and commissioned [156]. In line with this tendency, the recently approved European Commission RD II [6] establishes a minimum of $14 \%$ of the energy consumed in road and rail transport by 2030 as renewable energy, of which $3.5 \%$ must be advanced biofuels that comprise, among others, cellulosic ethanol. This scenario opens a great opportunity for boosting cellulosic ethanol production from nonfood/feed feedstocks such as those discussed in Section 2.

However, for the deployment and use of cellulosic ethanol at an extensive scale, it needs to be cost-effective and be produced in a sustainable way from an environmental point of view. In this context, the evolving concept of biorefinery can clearly contribute to reach such a goal through the introduction of more efficient biorefining technologies and the possibility to generate new value-added products resulting from a more integrated use of biomass feedstocks.

\subsection{Biorefinery: The Concept}

Biorefinery is a broad term that involves different sectors, such as transport, chemical, energy, agricultural, and forestry, and thus it is challenging to establish a single definition. For instance, according to the International Energy Agency (IEA) [157], biorefining is defined as "the sustainable processing of biomass into a spectrum of marketable bio-based products and bioenergy/biofuels, as an innovative and efficient approach to use available biomass resources for the synergistic coproduction of power, heat and biofuels alongside food and feed ingredients, pharmaceuticals, chemicals, materials, minerals and short-cyclic $\mathrm{CO}_{2}$ ". Other definitions refer to a biorefinery as "a facility for the synergetic processing of biomass into several marketable bio-based products (food and feed ingredients, chemicals, materials, minerals, $\mathrm{CO}_{2}$ ) and bioenergy (fuels, power, heat)" [158]. Biorefineries are, more generally, closely linked to the idea of a circular bio-based economy, which has been identified as a key priority to achieve an improvement in the efficiency and sustainability of the 
production and utilization of natural resources, as a response to the worldwide increment of the products and energy demand in the near future. In this regard, biorefinery is considered a strategic pillar of a bioeconomy-based scenario, in which biomass is converted into a wide range of bio-based products and energy carriers through a series of thermochemical and biochemical transformation processes in an integrated way.

Biorefinery is not a novel approach and currently there are several industrial facilities in operation that could be considered representative cases of existing biorefineries. Most of them are related to the pulp and paper and food industries, which probably represent the earlier cases of technology applications to convert biomass into valuable products. These facilities are focused on the production of relatively small amounts of higher value-added bio-based products and they usually produce energy (bioenergy) as a coproduct, in the so called "product-driven" biorefineries [159].

However, in recent decades the biorefinery concept has evolved towards a more ample concept that looks for a more sustainable and effective utilization of all biomass fractions, considering different feedstocks, process technologies, and final products. A key element in the advanced biorefinery approach is the use of a great diversity of biomasses (woody and herbaceous energy crops, as well as residues from forest and agriculture-related industries, urban wastes and aquaculture), into a wide portfolio of products and energy.

Due to the complexity of features intervening in a biorefinery, several classification approaches have been developed that utilize different features to define biorefinery types. An example is the classification system provided by Cherubini et al. [160] that distinguishes four main elements: feedstock, intermediate products or platforms, processes, and final products, applicable to define individual systems or combinations of them. Each element consists of several items that can be used to describe the different biorefinery configurations (Figure 2). According to the author, a biorefinery system is defined as a conversion route from raw material to products, through platforms and processes. The platforms are intermediates that are then converted into products. In the opinion of Hingsamer and Jungmeier [161], platforms are the most significant characteristic in a biorefinery, the number of them being an indication of the system complexity.

\begin{tabular}{|c|c|c|c|}
\hline Feedstock & Conversion process & Technological platform & Products \\
\hline $\begin{array}{l}\text { Dedicated crops } \\
\text { Oil-based } \\
\text { Sugar } \\
\text { Starch } \\
\text { Lignocellulose } \\
\text { Herbaceous/grasses } \\
\text { Macro/micro algae } \\
\text { Residucs } \\
\text { Oil-based } \\
\text { Lignocellulose } \\
\text { Agricultural and forest } \\
\text { Wood industry } \\
\text { Organic } \\
\text { Food industry } \\
\text { Urban waste } \\
\text { Manure }\end{array}$ & $\begin{array}{l}\text { Hydrolysis } \\
\text { (chemical, enzymatic) } \\
\text { Gasification } \\
\text { Combustion } \\
\text { Pyrolisis } \\
\text { Anaerobic digestion } \\
\begin{array}{l}\text { Extraction } \\
\text { (mechanical, chemical) }\end{array} \\
\begin{array}{l}\text { Separation } \\
\text { (mechanical, physical) }\end{array}\end{array}$ & $\begin{array}{l}\text { C6 \& C5 sugars } \\
\text { Lignin } \\
\text { Syngas } \\
\text { Electricity and heat } \\
\text { Pyrolisis oil } \\
\text { Biogas }\end{array}$ & $\begin{array}{l}\text { Biofuels (bioethanol, } \\
\text { biodiesel, biomethane, } \\
\text { synthetic biofuels) } \\
\text { Power and/or heat } \\
\text { Fine chemicals and } \\
\text { building blocks } \\
\text { Biomaterials } \\
\text { Food and animal feed } \\
\text { Biohydrogen } \\
\text { Polymers and resins } \\
\text { Glycerine }\end{array}$ \\
\hline
\end{tabular}

Figure 2. Main elements that make up biorefinery systems. Data from [160].

In recent decades, a great part of biorefinery applications have been developed in the field of energy products such as biofuels, power and heat, within the so-called "energydriven" concept of biorefineries. In fact, the production and development of biofuels, particularly road transportation biofuels as the cellulosic ethanol, has been claimed to be a key driver in recent biorefinery research [159]. However, as stated above in the introduction 
section, the cost-effectiveness and sustainability of the whole production process need to be improved and it is in this area where the advances in integrated biorefineries open promising possibilities.

Recently, the IEA Bioenergy organization [157] has published an interesting report on biorefinery concepts that includes a summary of the different biorefinery systems in progress with their corresponding level of development, quantified by their Technology Readiness Level (TRL) value (1 to 9). The classification feature used is the feedstock and the different biorefinery concepts encompass:

1. Conventional biorefineries: based on starch and sugar crops and wood, TRL 9;

2. Whole crop biorefineries: based on whole crop cereals (comprising straw), TRL 7-8;

3. Oleo-chemical biorefineries: using oily crops, TRL 7-9;

4. Lignocellulose biorefineries: with lignocellulosic biomass materials such as cereal straw, chaff, herbaceous biomass, woody residues, etc., TRL 6-8;

5. Green biorefineries: based on wet biomass, as green crops and leaves, grasses, etc., TRL 5-7;

6. Marine biorefineries: based on microalgae and macroalgae, TRL 5-6.

In the above classification, conventional biorefineries, which have reached the highest TRL value of 9, comprise existing industries such as the so-called first-generation biofuel industry (biodiesel and bioethanol) that uses edible crops as feedstocks, and mature technologies to produce the biofuels currently marketed for the transportation sector. Alternatively, lignocellulose biorefinery (LB), as a concept, shows marked promise as it has the potential to encompass an extensive variety of low-cost, nonfood feedstocks (straw, reeds, grass, wood, paper-waste, etc.), which could be converted into products for both the existing petrochemical-dominated market (e.g., 2G biofuels as cellulosic ethanol) and novel bio-based product markets [162]. LB allows avoiding the competition of raw materials in the food and energy markets and provides the means to advance the integration of different processing technologies to make a more efficient and sustainable use of all lignocellulosic biomass components. This biorefinery approach clearly connects to the idea of a circular bioeconomy and will contribute to improve the sustainability of the production systems and advance towards a different scenario in many production areas. In the next section, some innovative technologies and applications that will allow biomass use for material production to surpass biofuels are briefly presented.

\subsection{Lignocellulose-Based Biorefinery for the Production of Bioethanol and Bioproducts}

In the context of a biorefinery, lignocellulosic biomass can be processed under different processing routes, depending on the type of feedstock and product required. Often, several technologies must be applied subsequently, or in parallel, to produce the target product. Generally speaking, these technologies can be classified in four broad groups: thermochemical, biochemical, chemical and mechanical/physical and they can be used to convert lignocellulosic biomass into a vast array of energy-related (gaseous, solid and liquid biofuels) and nonenergy- or material-related products, such as chemicals, organic acids, polymers and resins, and biopolymers [162].

Over recent decades, a great part of the R\&D effort carried out in the field of LB has been focused on fuels and other energy-related products, with the cellulosic ethanol as one of the most significant examples of progress made in this field; nowadays, it is close to full commercialization. This scenario is the result of an intense R\&D work performed in the different steps of the biochemical pathway used to convert lignocellulosic biomass into cellulosic ethanol, as has been extensively described in this review. However, it is also acknowledged that its production cost is still too elevated to be competitive and that it is necessary to look for innovative approaches that result in a reduction in costs. In this context, recent advances in biocatalysts and microbial strains applied in the conversion route through the use of tools such as high-throughput screening, metagenomics techniques, metabolic engineering, and synthetic biology may enhance the potential for increased production and contribute to reach a more competitive product from an economic point of 
view $[163,164]$. At the same time, the utilization of such advanced techniques has permitted progress to be made in the production of bio-based products from lignocellulosic feedstocks that aim at substituting their fossil-fuel counterparts [165]. The vast number of compounds that can be derived from lignocellulosic biomass makes it difficult to present a succinct discussion on the possibilities for integration of ethanol production with other renewablebased chemicals. Thus, in this section only a few examples will be given, making clear that many other options are currently being explored.

Lignin, the third main biomass component in terms of importance, is a complex aromatic polymer that is processed together with carbohydrates in the biochemical conversion pathway to produce cellulosic ethanol from lignocellulosic biomass. Due to specific features such as aromatic structure, high reactive group content, and hydrophobicity, among others, lignin shows a high potential as a raw material to generate chemicals and materials. However, in many of LB systems it currently remains as a low purity component in the high-volume final residue generated after the different processing steps, usually being used as a solid fuel to produce heat and steam for plant operation. Thus, a great opportunity exists to look for feasible alternative processing routes to produce high-added value bioproducts and biofuels from lignin in the so-called lignin valorization platform within the LB concept [166]. On the other hand, lignin can be isolated and recovered throughout the pretreatment process by specific techniques to obtain a high-purity component for further valorization, as in the case of residual lignin from the lignocellulose-based industry. Lately, Susmozas et al. [167] have reviewed a series of potential bio-based products that could be generated in the lignin platform from the point of view of both its use as macromolecule with multiple functions and its depolymerization into low-molecular weight aromatics (including phenol, guaiacol, syringol, catechol, and cresol) for further conversion to fuels and chemicals [168]. The exhaustive list of potential products such as phenols, carbon fibers and materials, phenol formaldehyde resins, oleo-gels, and polymer blends have a large variety of applications in cosmetics, plastics, pharmaceuticals, or the fuel industry. More specifically, Liao et al. [169] propose an integrated biorefinery strategy to valorize birch wood for phenol, propylene, oligomers, and pulp production through a process that is able to convert $78 \%$ (weight basis) of initial birch biomass into those high-value bioproducts.

These are only few examples of significant research efforts that are currently being carried out to validate chemical and biological transformation routes to valorize lignin component into fuels, chemicals, and materials. As a result, several industries around the world have established pilot plants to obtain isolated lignins and lignin derivatives. A reference to those industries can be found in the paper by Chandel et al. [165], who cite CIMV (France) for lignin production, KMT Lignin Chemicals (UK) producing lignosulphonates for application in concrete admixtures, Green Value SA (Orbe, Switzerland) that has patented a fractionation technology to obtain high purity lignin, or Metgen Oy (Kaarina, Finland), the owner of METNIN ${ }^{\mathrm{TM}}$ technology, to obtain lignin-derived products from enzymatic refining lignin fractionates.

On the other hand, the LB concept triggers new possibilities for valorization of the C6 and C5 sugars derived from processing lignocellulosic biomass through pretreatment and hydrolysis steps, in the so-called "sugar platform" based biorefinery. Apart from the well-known bioalcohols butanol and ethanol produced by fermentation of sugars (mainly glucose), a large portfolio of bioproducts such as organic acids (succinic, glutamic, fumaric or aspartic), diols, lactic acid, itaconic acid, muconic acid (farnesene), xylitol, furans, and levulinic acid, among others, can also be obtained from both type of sugars via fermentation or chemical conversion $[115,165,166]$. This approach is particularly relevant for the C5 sugars from hemicellulose generated in the cellulosic conversion process, whose conversion to ethanol by fermentative yeasts in an LB still poses challenges related to strain robustness and tolerance to toxic metabolites, in spite of a large research effort to overcome them in recent decades. As in the case of lignin-derived products, the intense R\&D work has permitted several companies to get involved in the production of several bioproducts at different plant stages that can be considered the basis or intermediate chemicals for 
generating commodities. Examples can be the production of farnesene by the company Amyris (Emeryville, CA, USA), 5-HMF by AVA Biochem, (Zug, Switzerland), p-xylene in Virent, (Madison, WI, USA) or acrylic acid and adipic acid in ADM/LG Chem (Chicago, IL, USA; Seoul, Korea) and BASF (Ludwigshafen, Germany), respectively [165,166]. An interesting and extensive review of the different bioproducts that can be obtained together with cellulosic ethanol has been recently published by Rosales-Calderón and Arantes [115], who emphasize the high potential that the production of bio-based chemicals from cellulosederived sugars alongside ethanol has to improve the cost competitiveness of this biofuel.

In spite of the promising perspectives discussed above for the production of biobased chemicals in LB, techno-economic analyses are necessary to prove the feasibility of integrating the new processes in the future cellulosic ethanol plants. A good example of this approach can be found in the paper published by Susmozas et al. [170], who evaluated the feasibility of producing cellulosic ethanol, xylitol and antioxidants from the olive tree pruning (OTP) residue in an integrated biorefinery using the process simulation software Aspen Plus. The authors provided data on the economic profitability of the biorefinery and point out the opportunities for marketing several OTP-derived products. Additionally, the work of Liao et al. [169] cited above includes a techno-economic analysis of the proposed conversion process that shows a competitive production process from the economic point of view, and a life-cycle assessment that shows a lower carbon dioxide footprint in relation to that of fossil-based production.

Finally, it is important to point out that the development of biorefineries, such as LBs, apart from having a direct effect in the added value of biofuel/bioproduct obtained, can enlarge the opportunities for employment creation linked to the agriculture, chemical, and food processing industries, which is highly valuable in terms of enhancing the sustainability of the whole system from a socio-economic point of view. It is important to emphasize that support from public and private initiatives is essential to eventually make the deployment of this type of biorefinery a reality.

\section{Conclusions}

The strong efforts made in recent decades in research and development of the production of advanced bioethanol from lignocellulosic biomass through biochemical conversion processes (cellulosic ethanol) has resulted in this biofuel being a key element to meet the foreseen demand of bioethanol in the future. However, it is still necessary to enhance the production yields and reduce the costs to reach full commercialization of cellulosic ethanol. To reach this goal, the application of innovative and advanced approaches in the different steps of the conversion process has been claimed to be essential in order to achieve a more effective utilization of lignocellulosic biomass sources and, at the same time, increase the sustainability of the whole process. In this sense, the research community has been continuously working to provide technological advances in all stages of the lignocellulosic biomass to bioethanol value chain-from the use of alternative and promising biomass sources to the development of new and improved catalysts and microorganisms in the final conversion process steps. Moreover, the introduction of advanced processing technologies to generate new value-added products resulting from a more efficient and sustainable use of biomass feedstocks, within a biorefinery approach, has been identified as a very promising way to boost the production of biofuels such as cellulosic ethanol and other bio-based products. Eventually, these new approaches have to be tested and proved to be effective by the industrial developers, which undoubtedly represents a real challenge.

Author Contributions: Conceptualization, P.M. and A.D.M.; writing-original draft preparation, A.D., C.Á., P.D., and P.M.; writing—review and editing, A.D., C.Á., P.D., P.M., and A.D.M.; supervision, P.M. and A.D.M.; funding acquisition, P.M. All authors have read and agreed to the published version of the manuscript. 
Funding: This research was partially funded by the Regional Government of Madrid (Project BIOTRES S2018/EMT-4344), the Spanish MICIU (BIOREOL Project: ENE2017-85819-C2-2-R). The APC was funded by Processes Journal (ISSN 2227-9717).

Conflicts of Interest: The authors declare no conflict of interest. The funders had no role in the design of the study; in the collection, analyses, or interpretation of data; in the writing of the manuscript, or in the decision to publish the results.

\section{References}

1. IEA. Transport: Improving the Sustainability of Passenger and Freight Transport. Available online: https://www.iea.org/topics/ transport (accessed on 20 December 2020).

2. Papong, S.; Rewlay-ngoen, C.; Itsubo, N.; Malakul, P. Environmental life cycle assessment and social impacts of bioethanol production in Thailand. J. Clean. Prod. 2017, 157, 254-266. [CrossRef]

3. Islam, M.K.; Wang, H.; Rehman, S.; Dong, C.; Hsu, H.Y.; Lin, C.S.K.; Leu, S.Y. Sustainability metrics of pretreatment processes in a waste derived lignocellulosic biomass biorefinery. Bioresour. Technol. 2020, 298, 122558. [CrossRef]

4. RFA. 2020 RFA's Ethanol Industry Outlook; Renewable Fuels Association: Ellisvile, MO, USA, 2020; Available online: https: / / ethanolrfa.org/wp-content/uploads/2020/02/2020-Outlook-Final-for-Website.pdf (accessed on 1 September 2020).

5. EUBIA. Bioethanol; European Biomass Industry Association: Brussels, Belgium, 2020; Available online: https://www.eubia.org/ cms/wiki-biomass/biofuels/bioethanol/ (accessed on 20 December 2020).

6. EU. Directive (EU) 2018/2001 of the European Parliament and of the Council of 11 December 2018 on the Promotion of the Use of Energy from Renewable Sources. Available online: https: / eur-lex.europa.eu/eli/dir/2018/2001/oj (accessed on 1 November 2020).

7. Saini, J.K.; Saini, R.; Tewari, L. Lignocellulosic agriculture wastes as biomass feedstocks for second-generation bioethanol production: Concepts and recent developments. 3 Biotech 2015, 5, 337-353. [CrossRef] [PubMed]

8. Duque, A.; Doménech, P.; Álvarez, C.; Ballesteros, M.; Manzanares, P. Study of the bioprocess conditions to produce bioethanol from barley straw pretreated by combined soda and enzyme-catalyzed extrusion. Renew. Energy 2020, 158, 263-270. [CrossRef]

9. Kim, T.H.; Choi, C.H.; Oh, K.K. Bioconversion of sawdust into ethanol using dilute sulfuric acid-assisted continuous twin screw-driven reactor pretreatment and fed-batch simultaneous saccharification and fermentation. Bioresour. Technol. 2013, 130, 306-313. [CrossRef] [PubMed]

10. Isikgor, F.H.; Becer, C.R. Lignocellulosic biomass: A sustainable platform for the production of bio-based chemicals and polymers. Polym. Chem. 2015, 6, 4497-4559. [CrossRef]

11. Negro, M.J.; Álvarez, C.; Doménech, P.; Iglesias, R.; Ballesteros, I. Sugars production from municipal forestry and greening wastes pretreated by an integrated steam explosion-based process. Energies 2020, 13, 4432. [CrossRef]

12. Sathitsuksanoh, N.; Zhu, Z.; Zhang, Y.H.P. Cellulose solvent- and organic solvent-based lignocellulose fractionation enabled efficient sugar release from a variety of lignocellulosic feedstocks. Bioresour. Technol. 2012, 117, 228-233. [CrossRef]

13. Takara, D.; Khanal, S.K. Characterizing compositional changes of Napier grass at different stages of growth for biofuel and biobased products potential. Bioresour. Technol. 2015, 188, 103-108. [CrossRef]

14. Mohaptra, S.; Dash, P.K.; Behera, S.S.; Thatoi, H. Optimization of delignification of two Pennisetum grass species by NaOH pretreatment using Taguchi and ANN statistical approach. Environ. Technol. (UK) 2016, 37, 940-951. [CrossRef]

15. Dubois, J.L. Requirements for the development of a bioeconomy for chemicals. Curr. Opin. Environ. Sustain. 2011, 3, 11-14. [CrossRef]

16. BioEnergy_Europe. Bioenergy Europe Factsheet: Biomass for Energy_Agricultural Residues and Energy Crops; BioEnergy_Europe: Brussels, Belgium, 2019. Available online: https:/ / bioenergyeurope.org/article/204-bioenergy-explained-biomass-for-energyagricultural-residues-energy-crops.html (accessed on 20 December 2020).

17. IEA. Sustainable Production of Second-Generation Biofuels; IEA: Paris, France, 2010. Available online: https://www.iea.org/reports/ sustainable-production-of-second-generation-biofuels (accessed on 20 December 2020).

18. Smullen, E.; Finnan, J.; Dowling, D.; Mulcahy, P. Bioconversion of switchgrass: Identification of a leading pretreatment option based on yield, cost and environmental impact. Renew. Energy 2017, 111, 638-645. [CrossRef]

19. Hoadley, R.B. Understanding Wood: A Craftsman's Guide to Wood Technology; Taunton Press: Newtown, CT, USA, 2000.

20. Neiva, D.M.; Araújo, S.; Gominho, J.; Carneiro, A.d.C.; Pereira, H. Potential of Eucalyptus globulus industrial bark as a biorefinery feedstock: Chemical and fuel characterization. Ind. Crops Prod. 2018, 123, 262-270. [CrossRef]

21. Romaní, A.; Larramendi, A.; Yáñez, R.; Cancela, Á.; Sánchez, Á.; Teixeira, J.A.; Domingues, L. Valorization of Eucalyptus nitens bark by organosolv pretreatment for the production of advanced biofuels. Ind. Crops Prod. 2019, 132, 327-335. [CrossRef]

22. Zhao, J.; Tian, D.; Shen, F.; Hu, J.; Zeng, Y.; Huang, C. Valorizing waste lignocellulose-based furniture boards by phosphoric acid and hydrogen peroxide (Php) pretreatment for bioethanol production and high-value lignin recovery. Sustainability 2019, 11, 6175. [CrossRef]

23. Stichnothe, H.; Storz, H.; Meier, D.; de Bari, I.; Thomas, S. Development of second-generation biorefineries. In Developing the Global Bioeconomy: Technical, Market, and Environmental Lessons from Bioenergy; Lamers, P., Hess, J.R., Searcy, E., Stichnothe, H., Eds.; Academic Press: London, UK, 2016; pp. 11-40. [CrossRef] 
24. Sarkar, N.; Ghosh, S.K.; Bannerjee, S.; Aikat, K. Bioethanol production from agricultural wastes: An overview. Renew. Energy 2012, 37, 19-27. [CrossRef]

25. Rojas-Chamorro, J.A.; Romero, I.; López-Linares, J.C.; Castro, E. Brewer's spent grain as a source of renewable fuel through optimized dilute acid pretreatment. Renew. Energy 2020, 148, 81-90. [CrossRef]

26. FAO. Yearbook of Forest Products 2015; Food and Agriculture Organization of the United Nations: London, UK, 2017; Volume 2, pp. 397-467.

27. Pereira, S.R.; Sanchez, I.N.V.; Frazao, C.J.; Serafim, L.S.; Gorwa-Grauslund, M.F.; Xavier, A.M. Adaptation of Scheffersomyces stipitis to hardwood spent sulfite liquor by evolutionary engineering. Biotechnol. Biofuels 2015, 8, 50. [CrossRef]

28. Gottumukkala, L.D.; Haigh, K.; Collard, F.X.; van Rensburg, E.; Görgens, J. Opportunities and prospects of biorefinery-based valorisation of pulp and paper sludge. Bioresour. Technol. 2016, 215, 37-49. [CrossRef]

29. Schroeder, B.G.; Zanoni, P.R.S.; Magalhães, W.L.E.; Hansel, F.A.; Tavares, L.B.B. Evaluation of biotechnological processes to obtain ethanol from recycled paper sludge. J. Mater. Cycles Waste Manag. 2017, 19, 463-472. [CrossRef]

30. Nikolić, S.; Lazić, V.; Veljović, Đ.; Mojović, L. Production of bioethanol from pre-treated cotton fabrics and waste cotton materials. Carbohydr. Polym. 2017, 164, 136-144. [CrossRef] [PubMed]

31. Keshav, P.K.; Shaik, N.; Koti, S.; Linga, V.R. Bioconversion of alkali delignified cotton stalk using two-stage dilute acid hydrolysis and fermentation of detoxified hydrolysate into ethanol. Ind. Crops Prod. 2016, 91, 323-331. [CrossRef]

32. Wang, M.; Zhou, D.; Wang, Y.; Wei, S.; Yang, W.; Kuang, M.; Ma, L.; Fang, D.; Xu, S.; Du, S.k. Bioethanol production from cotton stalk: A comparative study of various pretreatments. Fuel 2016, 184, 527-532. [CrossRef]

33. Singh, J.; Sharma, A.; Sharma, P.; Singh, S.; Das, D.; Chawla, G.; Singha, A.; Nain, L. Valorization of jute (Corchorus sp.) biomass for bioethanol production. Biomass Convers. Biorefin. 2020. [CrossRef]

34. Eurostat. Municipal Waste Statistics. Available online: http:/ / appsso.eurostat.ec.europa.eu/nui/submitViewTableAction.do (accessed on 1 November 2020).

35. Tyagi, V.K.; Fdez-Güelfo, L.A.; Zhou, Y.; Álvarez-Gallego, C.J.; Garcia, L.I.R.; Ng, W.J. Anaerobic co-digestion of organic fraction of municipal solid waste (OFMSW): Progress and challenges. Renew. Sustain. Energy Rev. 2018, 93, 380-399. [CrossRef]

36. Moreno, A.D.; Magdalena, J.A.; Oliva, J.M.; Greses, S.; Coll Lozano, C.; Latorre-Sánchez, M.; Negro, M.J.; Susmozas, A.; Iglesias, R.; Llamas, M.; et al. Sequential bioethanol and methane production from municipal solid waste: An integrated biorefinery strategy towards cost-effectiveness. Process Saf. Environ. Prot. 2021, 146, 424-431. [CrossRef]

37. Chanoca, A.; de Vries, L.; Boerjan, W. Lignin Engineering in Forest Trees. Front. Plant Sci. 2019, 10. [CrossRef]

38. Boerjan, W.; Ralph, J.; Baucher, M. Lignin Biosynthesis. Annu. Rev. Plant Biol. 2003, 54, 519-546. [CrossRef]

39. Umezawa, T. Lignin modification in planta for valorization. Phytochem. Rev. 2018, 17, 1305-1327. [CrossRef]

40. Park, J.J.; Yoo, C.G.; Flanagan, A.; Pu, Y.; Debnath, S.; Ge, Y.; Ragauskas, A.J.; Wang, Z.Y. Defined tetra-allelic gene disruption of the 4-coumarate:coenzyme A ligase 1 (Pv4CL1) gene by CRISPR/Cas9 in switchgrass results in lignin reduction and improved sugar release Mike Himmel. Biotechnol. Biofuels 2017, 10, 284. [CrossRef]

41. Yang, Y.; Yoo, C.G.; Guo, H.B.; Rottmann, W.; Winkeler, K.A.; Collins, C.M.; Gunter, L.E.; Jawdy, S.S.; Yang, X.; Guo, H.; et al. Overexpression of a Domain of Unknown Function 266-containing protein results in high cellulose content, reduced recalcitrance, and enhanced plant growth in the bioenergy crop Populus. Biotechnol. Biofuels 2017, 10, 74. [CrossRef] [PubMed]

42. Mosier, N.; Wyman, C.; Dale, B.; Elander, R.; Lee, Y.Y.; Holtzapple, M.; Ladisch, M. Features of promising technologies for pretreatment of lignocellulosic biomass. Bioresour. Technol. 2005, 96, 673-686. [CrossRef] [PubMed]

43. Alvira, P.; Tomás-Pejó, E.; Ballesteros, M.; Negro, M.J. Pretreatment technologies for an efficient bioethanol production process based on enzymatic hydrolysis: A review. Bioresour. Technol. 2010, 101, 4851-4861. [CrossRef]

44. Galbe, M.; Zacchi, G. Pretreatment of lignocellulosic materials for efficient bioethanol production. Adv. Biochem. Eng. Biotechnol. 2007, 108, 41-65. [CrossRef] [PubMed]

45. Galbe, M.; Wallberg, O. Pretreatment for biorefineries: A review of common methods for efficient utilisation of lignocellulosic materials. Biotechnol. Biofuels 2019, 12, 294. [CrossRef] [PubMed]

46. Ruiz, H.A.; Conrad, M.; Sun, S.N.; Sanchez, A.; Rocha, G.J.M.; Romani, A.; Castro, E.; Torres, A.; Rodriguez-Jasso, R.M.; Andrade, L.P.; et al. Engineering aspects of hydrothermal pretreatment: From batch to continuous operation, scale-up and pilot reactor under biorefinery concept. Bioresour. Technol. 2020, 299, 122685. [CrossRef] [PubMed]

47. Perez-Cantu, L.; Schreiber, A.; Schutt, F.; Saake, B.; Kirsch, C.; Smirnova, I. Comparison of pretreatment methods for rye straw in the second generation biorefinery: Effect on cellulose, hemicellulose and lignin recovery. Bioresour. Technol. 2013, 142, 428-435. [CrossRef]

48. Huang, R.; Su, R.; Qi, W.; He, Z. Bioconversion of lignocellulose into bioethanol: Process intensification and mechanism research. Bioenergy Res. 2011, 4, 225-245. [CrossRef]

49. IRENA. Innovation Outlook. Advanced Liquid Biofuels; International Renewable Energy Agency: Abu Dhabi, UAE, 2016; Available online: https://www.irena.org/-/media/Files/IRENA/Agency/Publication/2016/IRENA_Innovation_Outlook_Advanced_ Liquid_Biofuels_2016.pdf (accessed on 1 November 2020).

50. Kumar, B.; Bhardwaj, N.; Agrawal, K.; Chaturvedi, V.; Verma, P. Current perspective on pretreatment technologies using lignocellulosic biomass: An emerging biorefinery concept. Fuel Process. Technol. 2020, 199, 106244. [CrossRef] 
51. Versalis. PROESA: Ethanol Production from Biomass. 2019. Available online: https://versalis.eni.com/irj/go/km/docs/ versalis/Contenuti\%20Versalis/IT/Documenti/Documentazione/Licensing/Biotech_0_/Proesa.pdf (accessed on 20 December 2020).

52. CLARIANT. Sunliquid. Cellulosic Ethanol from Agricultural Resiudes. Available online: https://www.clariant.com/en/ Solutions/Products/2014/10/16/16/16/sunliquid (accessed on 20 December 2020).

53. Yoo, C.G.; Meng, X.; Pu, Y.; Ragauskas, A.J. The critical role of lignin in lignocellulosic biomass conversion and recent pretreatment strategies: A comprehensive review. Bioresour. Technol. 2020, 301, 122784. [CrossRef]

54. Naresh Kumar, M.; Ravikumar, R.; Thenmozhi, S.; Ranjith Kumar, M.; Kirupa Shankar, M. Choice of pretreatment technology for sustainable production of bioethanol from lignocellulosic biomass: Bottle necks and recommendations. Waste Biomass Valorization 2018, 10, 1693-1709. [CrossRef]

55. Oliva, J.M.; Negro, M.J.; Manzanares, P.; Ballesteros, I.; Chamorro, M.A.; Sáez, F.; Ballesteros, M.; Moreno, A.D. A sequential steam explosion and reactive extrusion pretreatment for lignocellulosic biomass conversion within a fermentation-based biorefinery perspective. Fermentation 2017, 3, 15. [CrossRef]

56. Kim, S.M.; Dien, B.S.; Tumbleson, M.E.; Rausch, K.D.; Singh, V. Improvement of sugar yields from corn stover using sequential hot water pretreatment and disk milling. Bioresour. Technol. 2016, 216, 706-713. [CrossRef] [PubMed]

57. De Carvalho Silvello, M.A.; Martínez, J.; Goldbeck, R. Application of supercritical $\mathrm{CO}_{2}$ treatment enhances enzymatic hydrolysis of sugarcane bagasse. Bioenergy Res. 2020, 13, 786-796. [CrossRef]

58. Diez, V.; DeWeese, A.; Kalb, R.S.; Blauch, D.N.; Socha, A.M. Cellulose dissolution and biomass pretreatment using quaternary ammonium ionic liquids prepared from $\mathrm{H}_{-}, \mathrm{G}-$, and S-type lignin-derived benzaldehydes and dimethyl carbonate. Ind. Eng. Chem. Res. 2019, 58, 16009-16017. [CrossRef]

59. Kim, K.H.; Dutta, T.; Sun, J.; Simmons, B.; Singh, S. Biomass pretreatment using deep eutectic solvents from lignin derived phenols. Green Chem. 2018, 20, 809-815. [CrossRef]

60. Kang, K.E.; Park, D.H.; Jeong, G.T. Effects of inorganic salts on pretreatment of Miscanthus straw. Bioresour. Technol. 2013, 132, 160-165. [CrossRef]

61. Wi, S.G.; Choi, I.S.; Kim, K.H.; Kim, H.M.; Bae, H.J. Bioethanol production from rice straw by popping pretreatment. Biotechnol. Biofuels 2013, 6, 166. [CrossRef]

62. Liu, Y.; Zhou, H.; Wang, S.; Wang, K.; Su, X. Comparison of gamma-irradiation with other pretreatments followed with simultaneous saccharification and fermentation on bioconversion of microcrystalline cellulose for bioethanol production. Bioresour. Technol. 2015, 182, 289-295. [CrossRef]

63. Bak, J.S. Process evaluation of electron beam irradiation-based biodegradation relevant to lignocellulose bioconversion. SpringerPlus 2014, 3, 487. [CrossRef]

64. Mouthier, T.M.B.; de Rink, B.; van Erven, G.; de Gijsel, P.; Schols, H.A.; Kabel, M.A. Low liquid ammonia treatment of wheat straw increased enzymatic cell wall polysaccharide degradability and decreased residual hydroxycinnamic acids. Bioresour. Technol. 2019, 272, 288-299. [CrossRef] [PubMed]

65. Rehman, O.; Shahid, A.; Liu, C.-G.; Xu, J.-R.; Javed, M.R.; Eid, N.H.; Gull, M.; Nawaz, M.; Mehmood, M.A. Optimization of low-temperature energy-efficient pretreatment for enhanced saccharification and fermentation of Conocarpus erectus leaves to produce ethanol using Saccharomyces cerevisiae. Biomass Convers. Biorefin. 2019. [CrossRef]

66. Moreno, A.D.; Olsson, L. Pretreatment of lignocellulosic feedstocks. In Extremophilic Enzymatic Processing of Lignocellulosic Feedstocks to Bioenergy; Sani, R.K., Krishnaraj, R.N., Eds.; Springer International Publishing AG: Cham, Switzerland, 2017; pp. 31-52. [CrossRef]

67. Carrozza, C.F.; Papa, G.; Citterio, A.; Sebastiano, R.; Simmons, B.A.; Singh, S. One-pot bio-derived ionic liquid conversion followed by hydrogenolysis reaction for biomass valorization: A promising approach affecting the morphology and quality of lignin of switchgrass and poplar. Bioresour. Technol. 2019, 294, 122214. [CrossRef] [PubMed]

68. Kirupa Sankar, M.; Ravikumar, R.; Naresh Kumar, M.; Sivakumar, U. Development of co-immobilized tri-enzyme biocatalytic system for one-pot pretreatment of four different perennial lignocellulosic biomass and evaluation of their bioethanol production potential. Bioresour. Technol. 2018, 269, 227-236. [CrossRef] [PubMed]

69. Bibra, M.; Rathinam, N.K.; Johnson, G.R.; Sani, R.K. Single pot biovalorization of food waste to ethanol by Geobacillus and Thermoanaerobacter spp. Renew. Energy 2020, 155, 1032-1041. [CrossRef]

70. Zhong, Y.; Frost, H.; Bustamante, M.; Li, S.; Liu, Y.S.; Liao, W. A mechano-biocatalytic one-pot approach to release sugars from lignocellulosic materials. Renew. Sustain. Energy Rev. 2020, 121, 109675. [CrossRef]

71. Dong, Y.; Haverinen, J.; Tuuttila, T.; Jaakkola, M.; Holm, J.; Leveque, J.M.; Lassi, U. Rapid one-step solvent-free acid-catalyzed mechanical depolymerization of pine sawdust to high-yield water-soluble sugars. Biomass Bioenergy 2017, 102, 23-30. [CrossRef]

72. Dong, Y.; Schneider, L.; Hu, T.; Jaakkola, M.; Holm, J.; Leveque, J.M.; Lassi, U. Direct acid-catalysed mechanical depolymerisation of fibre sludge to reducing sugars using planetary milling. Biomass Bioenergy 2016, 86, 36-42. [CrossRef]

73. Schneider, L.; Haverinen, J.; Jaakkola, M.; Lassi, U. Pretreatment and fractionation of lignocellulosic barley straw by mechanocatalysis. Chem. Eng. J. 2017, 327, 898-905. [CrossRef]

74. Duque, A.; Manzanares, P.; Ballesteros, I.; Negro, M.J.; Oliva, J.M.; Gonzalez, A.; Ballesteros, M. Sugar production from barley straw biomass pretreated by combined alkali and enzymatic extrusion. Bioresour. Technol. 2014, 158, 262-268. [CrossRef] 
75. Grewal, J.; Khare, S.K. One-pot bioprocess for lactic acid production from lignocellulosic agro-wastes by using ionic liquid stable Lactobacillus brevis. Bioresour. Technol. 2018, 251, 268-273. [CrossRef] [PubMed]

76. Zhi, S.; Liu, Y.; Yu, X.; Wang, X.; Lu, X. Enzymatic hydrolysis of cellulose after pretreated by ionic liquids: Focus on one-pot process. Energy Procedia 2012, 14, 1741-1747. [CrossRef]

77. Althuri, A.; Venkata Mohan, S. Single pot bioprocessing for ethanol production from biogenic municipal solid waste. Bioresour. Technol. 2019, 283, 159-167. [CrossRef]

78. Vandenbossche, V.; Brault, J.; Vilarem, G.; Hernández-Meléndez, O.; Vivaldo-Lima, E.; Hernández-Luna, M.; Barzana, E.; Duque, A.; Manzanares, P.; Ballesteros, M.; et al. A new lignocellulosic biomass deconstruction process combining thermo-mechano chemical action and bio-catalytic enzymatic hydrolysis in a twin-screw extruder. Ind. Crops Prod. 2014, 55, 258-266. [CrossRef]

79. Xu, F.; Sun, J.; Konda, N.V.S.N.M.; Shi, J.; Dutta, T.; Scown, C.D.; Simmons, B.A.; Singh, S. Transforming biomass conversion with ionic liquids: Process intensification and the development of a high-gravity, one-pot process for the production of cellulosic ethanol. Energy Environ. Sci. 2016, 9, 1042-1049. [CrossRef]

80. Bernardo, J.R.; Girio, F.M.; Lukasik, R.M. The effect of the chemical character of ionic liquids on biomass pre-treatment and posterior enzymatic hydrolysis. Molecules 2019, 24, 808. [CrossRef] [PubMed]

81. Li, W.-C.; Zhang, S.-J.; Xu, T.; Sun, M.-Q.; Zhu, J.-Q.; Zhong, C.; Li, B.-Z.; Yuan, Y.-J. Fractionation of corn stover by two-step pretreatment for production of ethanol, furfural, and lignin. Energy 2020, 195, 117076. [CrossRef]

82. Dimos, K.; Paschos, T.; Louloudi, A.; Kalogiannis, K.G.; Lappas, A.A.; Papayannakos, N.; Kekos, D.; Mamma, D. Effect of various pretreatment methods on bioethanol production from cotton stalks. Fermentation 2019, 5, 5. [CrossRef]

83. Tang, S.; Cao, Y.; Xu, C.; Wu, Y.; Li, L.; Ye, P.; Luo, Y.; Gao, Y.; Liao, Y.; Yan, Q.; et al. One-step or two-step acid/alkaline pretreatments to improve enzymatic hydrolysis and sugar recovery from Arundo Donax L. Energies 2020, 13, 948. [CrossRef]

84. Wang, R.; Sun, Y.; Zhang, S.; Lu, X. Two-step pretreatment of corn stalk silage for increasing sugars production and decreasing the amount of catalyst. Bioresour. Technol. 2012, 120, 290-294. [CrossRef]

85. Bensah, E.C.; Mensah, M. Chemical pretreatment methods for the production of cellulosic ethanol: Technologies and innovations. Int. J. Chem. Eng. 2013, 2013, 719607. [CrossRef]

86. Soderstrom, J.; Pilcher, L.; Galbe, M.; Zacchi, G. Two-step steam pretreatment of softwood by diluted $\mathrm{H}_{2} \mathrm{SO}_{4}$ impregnation for ethanol production. Biomass Bioenergy 2003, 24, 475-486. [CrossRef]

87. Zhang, Y.; Fu, X.; Chen, H. Pretreatment based on two-step steam explosion combined with an intermediate separation of fiber cells-Optimization of fermentation of corn straw hydrolysates. Bioresour. Technol. 2012, 121, 100-104. [CrossRef] [PubMed]

88. Petersen, M.Ø.; Larsen, J.; Thomsen, M.H. Optimization of hydrothermal pretreatment of wheat straw for production of bioethanol at low water consumption without addition of chemicals. Biomass Bioenergy 2009, 33, 834-840. [CrossRef]

89. Yu, Q.; Zhuang, X.; Yuan, Z.; Wang, Q.; Qi, W.; Wang, W.; Zhang, Y.; Xu, J.; Xu, H. Two-step liquid hot water pretreatment of Eucalyptus grandis to enhance sugar recovery and enzymatic digestibility of cellulose. Bioresour. Technol. 2010, 101, 4895-4899. [CrossRef]

90. Dziekońska-Kubczak, U.; Berłowska, J.; Dziugan, P.; Patelski, P.; Balcerek, M.; Pielech-Przybylska, K.; Robak, K. Two-stage pretreatment to improve saccharification of oat straw and Jerusalem artichoke biomass. Energies 2019, 12, 1715. [CrossRef]

91. Hermosilla, E.; Rubilar, O.; Schalchli, H.; da Silva, A.S.; Ferreira-Leitao, V.; Diez, M.C. Sequential white-rot and brown-rot fungal pretreatment of wheat straw as a promising alternative for complementary mild treatments. Waste Manag. 2018, 79, 240-250. [CrossRef]

92. Kandasamy, M.; Hamawand, I.; Bowtell, L.; Seneweera, S.; Chakrabarty, S.; Yusaf, T.; Shakoor, Z.; Algayyim, S.; Eberhard, F. Investigation of ethanol production potential from lignocellulosic material without enzymatic hydrolysis using the ultrasound technique. Energies 2017, 10, 62. [CrossRef]

93. Liu, W.; Chen, W.; Hou, Q.; Wang, S.; Liu, F. Effects of combined pretreatment of dilute acid pre-extraction and chemical-assisted mechanical refining on enzymatic hydrolysis of lignocellulosic biomass. Rsc Adv. 2018, 8, 10207-10214. [CrossRef]

94. Shi, F.; Xiang, H.; Li, Y. Combined pretreatment using ozonolysis and ball milling to improve enzymatic saccharification of corn straw. Bioresour. Technol. 2015, 179, 444-451. [CrossRef]

95. Doménech, P.; Manzanares, P.; Álvarez, C.; Ballesteros, M.; Duque, A. Comprehensive study on the effects of process parameters of alkaline thermal pretreatment followed by thermomechanical extrusion in sugar liberation from Eucalyptus grandis wood. Holzforschung 2020. [CrossRef]

96. Padilla-Rascón, C.; Ruiz, E.; Romero, I.; Castro, E.; Oliva, J.M.; Ballesteros, I.; Manzanares, P. Valorisation of olive stone by-product for sugar production using a sequential acid/steam explosion pretreatment. Ind. Crops Prod. 2020, 148, 112279. [CrossRef]

97. Li, H.Y.; Chen, X.; Wang, C.Z.; Sun, S.N.; Sun, R.C. Evaluation of the two-step treatment with ionic liquids and alkali for enhancing enzymatic hydrolysis of Eucalyptus: Chemical and anatomical changes. Biotechnol. Biofuels 2016, 9, 166. [CrossRef] [PubMed]

98. Dai, Y.; Zhang, H.S.; Huan, B.; He, Y. Enhancing the enzymatic saccharification of bamboo shoot shell by sequential biological pretreatment with Galactomyces sp. CCZU11-1 and deep eutectic solvent extraction. Bioprocess Biosyst. Eng. 2017, 40, 1427-1436. [CrossRef] [PubMed]

99. Martínez-Patiño, J.C.; Lu-Chau, T.A.; Gullón, B.; Ruiz, E.; Romero, I.; Castro, E.; Lema, J.M. Application of a combined fungal and diluted acid pretreatment on olive tree biomass. Ind. Crops Prod. 2018, 121, 10-17. [CrossRef]

100. Yang, B.; Wyman, C.E. Pretreatment: The key to unlocking low-cost cellulosic ethanol. Biofuel Bioprod. Biorefin. 2008, 2, 26-40. [CrossRef] 
101. Ravindran, R.; Jaiswal, S.; Abu-Ghannam, N.; Jaiswal, A.K. Two-step sequential pretreatment for the enhanced enzymatic hydrolysis of coffee spent waste. Bioresour. Technol. 2017, 239, 276-284. [CrossRef]

102. Wyman, C.E.; Balan, V.; Dale, B.E.; Elander, R.T.; Falls, M.; Hames, B.; Holtzapple, M.T.; Ladisch, M.R.; Lee, Y.Y.; Mosier, N.; et al. Comparative data on effects of leading pretreatments and enzyme loadings and formulations on sugar yields from different switchgrass sources. Bioresour. Technol. 2011, 102, 11052-11062. [CrossRef]

103. Singh, S.; Cheng, G.; Sathitsuksanoh, N.; Wu, D.; Varanasi, P.; George, A.; Balan, V.; Gao, X.; Kumar, R.; Dale, B.E.; et al. Comparison of different biomass pretreatment techniques and their impact on chemistry and structure. Front. Energy Res. 2015, 2. [CrossRef]

104. Julio, R.; Albet, J.; Vialle, C.; Vaca-Garcia, C.; Sablayrolles, C. Sustainable design of biorefinery processes: Existing practices and new methodology. Biofuels Bioprod. Biorefin. 2017, 11, 373-395. [CrossRef]

105. Gnansounou, E.; Dauriat, A. Techno-economic analysis of lignocellulosic ethanol: A review. Biosurce Technol. 2010, 10, 4980-4991. [CrossRef] [PubMed]

106. Soltanian, S.; Aghbashlo, M.; Almasi, F.; Hosseinzadeh-Bandbafha, H.; Nizami, A.-S.; Ok, Y.S.; Lam, S.S.; Tabatabaei, M. A critical review of the effects of pretreatment methods on the exergetic aspects of lignocellulosic biofuels. Energy Convers. Manag. 2020, 212, 112792. [CrossRef]

107. Vannarath, A.; Thalla, A.K. Evaluation, ranking, and selection of pretreatment methods for the conversion of biomass to biogas using multi-criteria decision-making approach. Environ. Syst. Decis. 2019, 40, 510-525. [CrossRef]

108. Mussatto, S.I.; Teixeira, J.A. Lignocellulose as raw material in fermentation processes. In Current Research, Technology and Education Topics in Applied Microbiology and Microbial Biotechnology; Méndez-Vilas, A., Ed.; FORMATEX: Badajoz, Spain, 2010; Volume 2, pp. 897-907.

109. Balat, M. Production of bioethanol from lignocellulosic materials via the biochemical pathway: A review. Energy Convers. Manag. 2011, 52, 858-875. [CrossRef]

110. Kang, Q.; Appels, L.; Tan, T.; Dewil, R. Bioethanol from lignocellulosic biomass: Current findings determine research priorities. Sci. World J. 2014, 2014, 13. [CrossRef] [PubMed]

111. Moreno, A.D.; Alvira, P.; Ibarra, D.; Tomás-Pejó, E. Production of ethanol from lignocellulosic biomass. In Production of Platform Chemicals from Sustainable Resources; Fang, Z., Smith, R.L., Qi, X., Eds.; Springer Nature: Singapore, 2017; pp. 375-410. [CrossRef]

112. Jørgensen, H.; Kristensen, J.B.; Felby, C. Enzymatic conversion of lignocellulose into fermentable sugars: Challenges and opportunities. Biofuel Bioprod. Biorefin. 2007, 1, 119-134. [CrossRef]

113. Da Silva, A.S.; Espinheira, R.P.; Teixeira, R.S.S.; de Souza, M.F.; Ferreira-Leitao, V.; Bon, E.P.S. Constraints and advances in high-solids enzymatic hydrolysis of lignocellulosic biomass: A critical review. Biotechnol. Biofuels 2020, 13, 58. [CrossRef]

114. Jørgensen, H.; Pinelo, M. Enzyme recycling in lignocellulosic biorefineries. Biofuels bioprod. Biorefin. 2016, 11, 150-167. [CrossRef]

115. Rosales-Calderón, O.; Arantes, V. A review on commercial-scale high-value products that can be produced alongside cellulosic ethanol. Biotechnol. Biofuels 2019, 12, 240. [CrossRef]

116. Eriksson, T.; Börjesson, J.; Tjerneld, F. Mechanism of surfactant effect in enzymatic hydrolysis of lignocellulose. Enzym. Microb. Technol. 2002, 31, 353-364. [CrossRef]

117. Parnthong, J.; Kungsanant, S.; Chavadej, S. Enhancement of enzymatic hydrolysis of lignocellulosic materials by nonionic surfactant. Key Eng. Mater. 2017, 757, 151-155. [CrossRef]

118. Luo, X.; Liu, J.; Zheng, P.; Li, M.; Zhou, Y.; Huang, L.; Chen, L.; Shuai, L. Promoting enzymatic hydrolysis of lignocellulosic biomass by inexpensive soy protein. Biotechnol. Biofuels 2019, 12, 51. [CrossRef] [PubMed]

119. Rocha-Martin, J.; Martinez-Bernal, C.; Perez-Cobas, Y.; Reyes-Sosa, F.M.; Garcia, B.D. Additives enhancing enzymatic hydrolysis of lignocellulosic biomass. Bioresour. Technol. 2017, 244, 48-56. [CrossRef] [PubMed]

120. Baral, P.; Jain, L.; Kurmi, A.K.; Kumar, V.; Agrawal, D. Augmented hydrolysis of acid pretreated sugarcane bagasse by PEG 6000 addition: A case study of Cellic CTec2 with recycling and reuse. Bioprocess Biosyst. Eng. 2020, 43, 473-482. [CrossRef] [PubMed]

121. Yang, M.; Zhang, J.; Kuittinen, S.; Vepsalainen, J.; Soininen, P.; Keinanen, M.; Pappinen, A. Enhanced sugar production from pretreated barley straw by additive xylanase and surfactants in enzymatic hydrolysis for acetone-butanol-ethanol fermentation. Bioresour. Technol. 2015, 189, 131-137. [CrossRef]

122. Li, K.; Wang, X.; Wang, J.; Zhang, J. Benefits from additives and xylanase during enzymatic hydrolysis of bamboo shoot and mature bamboo. Bioresour. Technol. 2015, 192, 424-431. [CrossRef]

123. Martínez-Alcalá García, Á. Producción de Bioetanol: Mejora del Proceso a Partir de Grano de Cereal y de Biomasa Lignocelulósica Tratada con Steam Explosion. Ph.D. Thesis, Universidad Complutense de Madrid, Madrid, Spain, 2012.

124. Bajaj, P.; Mahajan, R. Cellulase and xylanase synergism in industrial biotechnology. Appl. Microbiol. Biotechnol. 2019, 103, 8711-8724. [CrossRef]

125. Cintra, L.C.; da Costa, I.C.; de Oliveira, I.C.M.; Fernandes, A.G.; Faria, S.P.; Jesuino, R.S.A.; Ravanal, M.C.; Eyzaguirre, J.; Ramos, L.P.; de Faria, F.P.; et al. The boosting effect of recombinant hemicellulases on the enzymatic hydrolysis of steam-treated sugarcane bagasse. Enzym. Microb. Technol. 2020, 133, 109447. [CrossRef]

126. Pengilly, C.; García-Aparicio, M.P.; Diedericks, D.; Görgens, J.F. Optimization of enzymatic hydrolysis of steam pretreated triticale straw. Bioenergy Res. 2016, 9, 851-863. [CrossRef]

127. Johansen, K.S. Discovery and industrial applications of lytic polysaccharide mono-oxygenases. Biochem. Soc. Trans. 2016, 44, 143-149. [CrossRef] 
128. Müller, G.; Várnai, A.; Johansen, K.S.; Eijsink, V.G.; Horn, S.J. Harnessing the potential of LPMO-containing cellulase cocktails poses new demands on processing conditions. Biotechnol. Biofuels 2015, 8, 187. [CrossRef] [PubMed]

129. Corrêa, T.L.R.; dos Santos, L.V.; Pereira, G.A.G. AA9 and AA10: From enigmatic to essential enzymes. Appl. Microbiol. Biotechnol. 2016, 100, 9-16. [CrossRef] [PubMed]

130. Rodríguez-Zúñiga, U.F.; Cannella, D.; de Campos Giordano, R.; de Lima Camargo Giordano, R.; Jørgensen, H.; Felby, C. Lignocellulose pretreatment technologies affect the level of enzymatic cellulose oxidation by LPMO. Green Chem. 2015, 17, 2896-2903. [CrossRef]

131. Scott, B.R.; Huang, H.Z.; Frickman, J.; Halvorsen, R.; Johansen, K.S. Catalase improves saccharification of lignocellulose by reducing lytic polysaccharide monooxygenase-associated enzyme inactivation. Biotechnol. Lett. 2016, 38, 425-434. [CrossRef]

132. Agrawal, D.; Kaur, B.; Kaur Brar, K.; Chadha, B.S. An innovative approach of priming lignocellulosics with lytic polysaccharide mono-oxygenases prior to saccharification with glycosyl hydrolases can economize second generation ethanol process. Bioresour. Technol. 2020, 308, 123257. [CrossRef]

133. Zhang, R.; Liu, Y.; Zhang, Y.; Feng, D.; Hou, S.; Guo, W.; Niu, K.; Jiang, Y.; Han, L.; Sindhu, L.; et al. Identification of a thermostable fungal lytic polysaccharide monooxygenase and evaluation of its effect on lignocellulosic degradation. Appl. Microbiol. Biotechnol. 2019, 103, 5739-5750. [CrossRef]

134. Ladevèze, S.; Haon, M.; Villares, A.; Cathala, B.; Grisel, S.; Herpoël-Gimbert, I.; Henrissat, B.; Berrin, J.G. The yeast Geotrichum candidum encodes functional lytic polysaccharide monooxygenases. Biotechnol. Biofuels 2017, 10, 215. [CrossRef]

135. Dien, B.S.; Cotta, M.A.; Jeffries, T.W. Bacteria engineered for fuel ethanol production: Current status. Appl. Microbiol. Biotechnol. 2003, 63, 258-266. [CrossRef]

136. Liu, C.G.; Xiao, Y.; Xia, X.X.; Zhao, X.Q.; Peng, L.; Srinophakun, P.; Bai, F.W. Cellulosic ethanol production: Progress, challenges and strategies for solutions. Biotechnol. Adv. 2019, 37, 491-504. [CrossRef]

137. Ruchala, J.; Kurylenko, O.O.; Dmytruk, K.V.; Sibirny, A.A. Construction of advanced producers of first- and second-generation ethanol in Saccharomyces cerevisiae and selected species of non-conventional yeasts (Scheffersomyces stipitis, Ogataea polymorpha). J. Ind. Microbiol. Biotechnol. 2020, 47, 109-132. [CrossRef]

138. Lallemand; Taurus. XyloFerm ${ }^{\circledR}$. Cellulosic Yeast for G2 Ethanol Production (Product Sheet). 2015. Available online: https: //www.lallemandbds.com/products/xyloferm/ (accessed on 1 November 2020).

139. Lesaffre. CelluX $X^{\mathrm{TM}}$. Cellulosic Ethanol Is Now a Reality. Available online: https://lesaffreadvancedfermentations.com/cellulosic_ ethanol_yeast/ (accessed on 20 December 2020).

140. Lallemand. C5 FUEL ${ }^{\mathrm{TM}}$. High Performance Liquid Yeast. 2015. Available online: https://www.lallemandbds.com/wp-content/ uploads/2015/06/C5Fuel_ProductSheetupdates1.pdf (accessed on 20 December 2020).

141. Yamakawa, C.K.; Kastell, L.; Mahler, M.R.; Martinez, J.L.; Mussatto, S.I. Exploiting new biorefinery models using non-conventional yeasts and their implications for sustainability. Bioresour Technol. 2020, 309, 123374. [CrossRef] [PubMed]

142. Murata, M.; Nitiyon, S.; Lertwattanasakul, N.; Sootsuwan, K.; Kosaka, T.; Thanonkeo, P.; Limtong, S.; Yamada, M. Hightemperature Fermentation Technology for Low-cost Bioethanol. J. Jpn. Inst. Energy 2015, 94, 1154-1162. [CrossRef]

143. Leandro, M.J.; Marques, S.; Ribeiro, B.; Santos, H.; Fonseca, C. Integrated process for bioenergy production and water recycling in the dairy industry: Selection of Kluyveromyces strains for direct conversion of concentrated lactose-rich streams into bioethanol. Microorganisms 2019, 7, 545. [CrossRef] [PubMed]

144. Haq, I.U.; Manzoor, Z.; Rehman, A.U.; Mukhtar, H. A new multi-stress resistant Wickerhamomyces anomalus: Isolation, identification and bioethanol fermentation potential. Rev. Mex. De Ing. Química 2019, 18, 841-849. [CrossRef]

145. Thontowi, A.; Perwitasari, U.; Kholida, L.N.; Kanti, A.; Yopi, Y.; Prasetya, B. Furfural and 5-(hydroxymethyl) furfural tolerance Candida strains in bioethanol fermentation. Ann. Bogor. 2020, 24, 1. [CrossRef]

146. Oshoma, C.E.; Greetham, D.; Louis, E.J.; Smart, K.A.; Phister, T.G.; Powell, C.; Du, C. Screening of non-Saccharomyces cerevisiae strains for tolerance to formic acid in bioethanol fermentation. PLoS ONE 2015, 10, e0135626. [CrossRef]

147. Mukherjee, V.; Radecka, D.; Aerts, G.; Verstrepen, K.J.; Lievens, B.; Thevelein, J.M. Phenotypic landscape of non-conventional yeast species for different stress tolerance traits desirable in bioethanol fermentation. Biotechnol. Biofuels 2017, 10, 216. [CrossRef]

148. Mergner, R.; Janssen, R.; Rutz, D.; de Bari, I.; Sissot, F.; Chiaramonti, D.; Giovannini, A.; Pescarolo, S.; Nistri, R. Fermentation and process configurations. In Lignocellulosic Ethanol Process and Demonstration: A Handbook; Chiaramonti, D., Giovannini, A., Janssen, R., Mergner, R., Eds.; WIP Renewable Energies: Munich, Germany, 2013.

149. Maulana Hidayatullah, I.; Setiadi, T.; Tri Ari Penia Kresnowati, M.; Boopathy, R. Xylanase inhibition by the derivatives of lignocellulosic material. Bioresour. Technol. 2020, 300, 122740. [CrossRef]

150. Cannella, D.; Jørgensen, H. Do new cellulolytic enzyme preparations affect the industrial strategies for high solids lignocellulosic ethanol production? Biotechnol. Bioeng. 2014, 111, 59-68. [CrossRef]

151. Silva, C.O.G.; Aquino, E.N.; Ricart, C.A.O.; Midorikawa, G.E.O.; Miller, R.N.G.; Filho, E.X.F. GH11 xylanase from Emericella nidulans with low sensitivity to inhibition by ethanol and lignocellulose-derived phenolic compounds. FEMS Microbiol. Lett. 2015, 362, fnv094. [CrossRef]

152. Xue, D.; Zeng, X.; Lin, D.; Yao, S. Thermostable ethanol tolerant xylanase from a cold-adapted marine species Acinetobacter johnsonii. Chin. J. Chem. Eng. 2019, 27, 1166-1170. [CrossRef]

153. Chylenski, P.; Bissaro, B.; Sørlie, M.; Røhr, Å.K.; Várnai, A.; Horn, S.J.; Eijsink, V.G.H. Lytic polysaccharide monooxygenases in enzymatic processing of lignocellulosic biomass. ACS Catal. 2019, 9, 4970-4991. [CrossRef] 
154. Ahorsu, R.; Medina, F.; Constantí, M. Significance and Challenges of Biomass as a Suitable Feedstock for Bioenergy and Biochemical Production: A Review. Energies 2018, 11, 3366. [CrossRef]

155. Adams, P.; Bridgwater, T.; Lea-Langton, A.; Ross, A.; Watson, I. Biomass Conversion Technologies. In Greenhouse Gas Balances of Bioenergy Systems; Thornley, P., Adams, P., Eds.; Academic Press: London, UK, 2018; pp. 107-139. [CrossRef]

156. Padella, M.; O'Connell, A.; Prussi, M. What is still limiting the deployment of cellulosic ethanol? Analysis of the current status of the sector. Appl. Sci. (Switz.) 2019, 9, 4523. [CrossRef]

157. Lindorfer, J.; Lettner, M.; Fazeni, K.; Rosenfeld, D.; Annevelink, B.; Mandl, M. Technical, Economic and Environmental Assessment of Biorefinery Concepts; IEA Bioenergy: Paris, France, 2019. Available online: https://www.ieabioenergy.com/wp-content/uploads/ 2019/07/TEE_assessment_report_final_20190704-1.pdf (accessed on 1 November 2020).

158. ETIP. Biorefinery Concepts; European Technology and Innovation Platform Bioenergy: Gülzow, Germany, 2017. Available online: https:/ / etipbioenergy.eu/images/ETIP_Bioenergy_Factsheet_Biorefinery_concepts.pdf (accessed on 1 November 2020).

159. Wenger, J.; Stern, T. Reflection on the research on and implementation of biorefinery systems-a systematic literature review with a focus on feedstock. Biofuels Bioprod. Biorefin. 2019, 13, 1347-1364. [CrossRef]

160. Cherubini, F.; Jungmeier, G.; Wellisch, M.; Willke, T.; Skiadas, I.; Van Ree, R.; de Jong, E. Toward a common classification approach for biorefinery systems. Biofuels Bioprod. Biorefin. 2009, 3, 534-546. [CrossRef]

161. Hingsamer, M.; Jungmeier, G. Biorefineries. In The Role of Bioenergy in the Bioeconomy; Lago, C., Caldés, N., Lechón, Y., Eds.; Academic Press: Cambridge, MA, USA, 2019; pp. 179-222. [CrossRef]

162. Chaturvedi, T.; Torres, A.I.; Stephanopoulos, G.; Thomsen, M.H.; Schmidt, J.E. Developing Process Designs for BiorefineriesDefinitions, Categories, and Unit Operations. Energies 2020, 13, 1493. [CrossRef]

163. Jeevan Kumar, S.P.; Sampath Kumar, N.S.; Chintagunta, A.D. Bioethanol production from cereal crops and lignocelluloses rich agro-residues: Prospects and challenges. SN Appl. Sci. 2020, 2, 163. [CrossRef]

164. Baral, N.R.; Sundstrom, E.R.; Das, L.; Gladden, J.; Eudes, A.; Mortimer, J.C.; Singer, S.W.; Mukhopadhyay, A.; Scown, C.D. Approaches for More Efficient Biological Conversion of Lignocellulosic Feedstocks to Biofuels and Bioproducts. ACS Sustain. Chem. Eng. 2019, 7, 9062-9079. [CrossRef]

165. Chandel, A.K.; Garlapati, V.K.; Jeevan Kumar, S.P.; Hans, M.; Singh, A.K.; Kumar, S. The role of renewable chemicals and biofuels in building a bioeconomy. Biofuels Bioprod. Biorefin. 2020, 14, 830-844. [CrossRef]

166. Chandel, A.K.; Garlapati, V.K.; Singh, A.K.; Antunes, F.A.F.; da Silva, S.S. The path forward for lignocellulose biorefineries: Bottlenecks, solutions, and perspective on commercialization. Bioresour. Technol. 2018, 264, 370-381. [CrossRef] [PubMed]

167. Susmozas, A.; Martín-Sampedro, R.; Ibarra, D.; Eugenio, M.E.; Iglesias, R.; Manzanares, P.; Moreno, A.D. Process Strategies for the Transition of $1 \mathrm{G}$ to Advanced Bioethanol Production. Processes 2020, 8, 1310. [CrossRef]

168. Davis, K.; Rover, M.; Brown, R.; Bai, X.; Wen, Z.; Jarboe, L. Recovery and Utilization of Lignin Monomers as Part of the Biorefinery Approach. Energies 2016, 9, 808. [CrossRef]

169. Liao, Y.; Koelewijn, S.F.; Van den Bossche, G.; Van Aelst, J.; Van den Bosch, S.; Renders, T.; Navare, K.; Nicolai, T.; Van Aelst, K.; Maesen, M.; et al. A sustainable wood biorefinery for low-carbon footprint chemicals production. Science 2020, 367, 1385-1390. [CrossRef] [PubMed]

170. Susmozas, A.; Moreno, A.D.; Romero-García, J.M.; Manzanares, P.; Ballesteros, M. Designing an olive tree pruning biorefinery for the production of bioethanol, xylitol and antioxidants: A techno-economic assessment. Holzforschung 2018, 73, 15-23. [CrossRef] 